\title{
Juvenile Justice and the Punishment of Recidivists Under California's Three Strikes Law
}

\author{
Amanda K. Packel $\uparrow$
}

The inclusion of juvenile adjudications as prior strikes under California's Three Strikes law sets up an inevitable clash between the remaining rehabilitative purposes of the juvenile justice system and the punitive intent that motivated Three Strikes. The California Supreme Court, faced with a poorly written statute, has dealt with the statute's ambiguities in a way that has further confused the rules and obfuscated the rationales behind them. In People v. Davis, the court ignored traditional canons of statutory construction and unjustifiably expanded the number of juvenile adjudications that can count as strikes. In People v. Garcia, when the court finally recognized a distinction for the use of juvenile adjudications as strikes, it did so reluctantly and without acknowledging that it was in effect overruling Davis. The supreme court should expressly overrule Davis, including its methods of statutory interpretation and its broadening of the scope of juvenile adjudications that qualify as prior strikes. Trial and appellate courts should use their discretion to dismiss prior juvenile adjudication strikes and resolve the tension created by Three Strikes's application to juvenile adjudications and exacerbated by the Davis and Garcia opinions. This Comment also suggests a number of other ways that juvenile court judges, criminal court judges, and legislators can reduce the conflict between the juvenile justice system and the Three Strikes fueled criminal justice system in California.

Copyright @2002 California Law Review, Inc. California Law Review, Inc. (CLR) is a California nonprofit corporation. CLR and the authors are solely responsible for the content of their publications.

$\dagger$ Young Scholar, The Earl Warren Legal Institute, University of California, Berkeley, Summer 2002; Law Clerk, The Honorable Marsha S. Berzon, United States Court of Appeals for the Ninth Circuit, 2001-2002; J.D., School of Law, University of California, Berkeley (Boalt Hall), 2001; A.B., Princeton University, 1996. I am extrennely grateful to Professor Franklin E. Zimring for his guidance and patience throughout the development of this piece. I would also like to thank Sam Weinstein, Gabriela Gallegos, and the other meinbers of the California Law Review who helped prepare this Comment for publication. Of course, any errors are mine alone. Lastly, I would like to thank iny mother, Doreen, and my sisters, Lisa and Laura, for their ever-present support and encouragement. 


\section{INTRODUCTION}

The passage of California's Three Strikes law" ("Three Strikes") in 1994 has engendered fierce debate over the fairness of using prior offenses to impose harsh mandatory punishments. ${ }^{2}$ Habitual-offender statutes are not a new phenomenon, ${ }^{3}$ but the mandatory nature and broad scale of the California statute distinguishes it from all other habitual-offender statutes, and even from all other Three Strikes laws. ${ }^{4}$ The application of these mandatory penalties is particularly controversial when the prior strikes include juvenile adjudications. ${ }^{5}$ Drafting Three Strikes to include certain juvenile adjudications as prior strikes inevitably prompted a clash between its purpose and the purpose of the juvenile justice system. Three Strikes was driven by punitive intent while the juvenile system still retains, to some extent, its original goals of rehabilitating juveniles and rescuing them from the harsh treatment and permanent consequences of crimimal courts.

Including juvenile adjudications as strikes raises serious questions of constitutionality and fairness. ${ }^{6}$ The California Supreme Court has twice addressed the Three Strikes provision defining the scope of juvenile adjudications that constitute strikes. The two opinions are both unclear and contradictory. An examination of these two cases reveals that the supreme court has been inconsistent in its position on whether Three Strikes's

1. Cal. Penal Code $\S 667(b)$-(i), amended by 1994 Cal. Stat. 12, § 1 (legislative version effective Mar. 7, 2000); Proposition 184, approved by voters Gen. Elee. (Nov. 8, 1994) (adding CaL. Penal Code $\$ 1170.12$ ).

2. For an overview of arguments in favor of and against Three Strikes, see Erik G. Luna, Three Strikes in a Nutshell, 20 T. JefFERSON L. Rev. 1, 12-32 (1998).

3. See Norval Morris, The Habitual Criminal (1951).

4. See Franklin E. Zimring et al., Punishment and Democracy: Three Strikes and You're Out in California 21, fig. 2.2 (2001) [hereinafter Punishment and Democracy] (demonstrating in a frequency distribution that as of 1998, California had vastly more Three Strikes eonvictions than any other state). Several features combine to make Three Strikes particularly harsh. First, the triggering offense may be any felony under California law. CAL. PEnal Code $\S 667(e)(1)$, (2)(A) (Deering 1998). Second, a defendant may receive two prior strikes from a single incident, People v. Benson, 954 P.2d 557 (Cal. 1998), or from a single proceeding, People v. Askey, 56 Cal. Rptr. 2d 782, 785 (Cal. Ct. App. 1996). Third, prior strikes include not only violent felonies, but also serious felonies, Cal. PEnal Code $\S 667$ (d)(I) (Deering 1998), and some juvenile adjudications, id. $\S 667(d)(3)$. Fourth, there is no "washout" period after which prior convictions will no longer count as strikes. Id. $\S 667(\mathrm{c})(3)$. Fifth, defendants with prior strikes who are convicted of multiple current felonies committed on different occasions must serve consecutive sentences. Id. $\S 667(\mathrm{c})(6)$.

5. See Walter L. Gordon 1ll, California's Three Strikes Law: Tyranny of the Majority, 20 WHitTIER L. REv. 577, 598 (1999) ("The law has the effect of penalizing minors who stay in juvenile court when the rationale for keeping them in juvenile court is to protect them.") See also Francis T. Cullen, Bonnie S. Fisher, \& Brandon K. Applegate, Public Opinion About Punishment and Correction, 27 CRIME \& JUST. 1, 38-40, 55-56 (2000) (citing data showing public support of the purposes of the juvenile system: $78 \%$ support rehabilitation and treatment, $12 \%$ support punishment, and $10 \%$ support rehabilitation and punishment equally). But see Phil Wyman \& John G. Schmidt, Jr., Three Strikes and You're Out (It's About Time), 26 UWLA L. REv. 249, 254 (1995) (arguing that disallowing juvenile adjudications as strikes "would only reward society with 'more blood-soaked victims").

6. See Luna, supra note 2 , at 78-79. 
drafters intended juvenile adjudications to be treated differently than other prior convictions.

This Comment attenipts to expose the hidden contradictions in the California Suprenie Court's treatment of the juvenile adjudication provision of Three Strikes. Part I discusses the history of the juvenile justice systen in California and explores the ambivalent jurisprudence of juvenile justice in the state. Part II provides an overview of the operation of Three Strikes, exanining the statute's provisions and the California Suprenie Court's treatment of it. Part III analyzes the two California Supreme Court cases that interpret the Three Strikes provision that defines the four requirements for juvenile adjudications to count as strikes. ${ }^{7}$ First, this Part discusses People v. Davis, ${ }^{8}$ which interpreted one of the requirements for a juvenile adjudication to count as a strike ${ }^{9}$ so broadly that the court deenied the circumstance present in every juvenile adjudication, effectively eliminating it as a factor. Next, this Part examines People v. Garcia, ${ }^{10}$ which interpreted a paragraph of the same provision ${ }^{11}$ but invoked methods of reasoning and statutory construction that conipletely contradict the framework employed in Davis. Last, this Part reveals the tensions between the court's two opinions by applying the methods of Garcia to the issue in Davis, concluding that Davis would have yielded the opposite result if the Davis court had applied Garcia's methods. Part IV proposes methods for resolving the tension between the two decisions, describing actions that the state supreme court, appellate courts, trial courts, state legislators, and juvenile court judges can take to acknowledge that Garcia has effectively undermined Davis. An explicit overruling of Davis would be a doctrinal improvenient of California law that carries no cost in crime control effectiveness. Thus, the California Supreme Court should change its interpretation of the provision governing the applicability of Three Strikes to prior juvenile adjudications to conforn to the text of the statute.

\section{I}

The Special Status of Juvenile Offenders and Ambivalent JuRISPRUDENCE OF JuvENILE JUSTICE IN CALIFORNIA

Before the juvenile justice systenı was formed, children were either not prosecuted at all, or they were prosecuted in the crininal courts along with all other criminal defendants. ${ }^{12}$ After the juvenile justice systenı was

7. Cal. Penal Code $\$ 667(d)(3)(A)$-(D) (Deering 1998).

8. 938 P.2d 938 (Cal. 1997).

9. Cal. Penal Code $§ 667$ (d)(3)(C) (Deering 1998).

10. 980 P.2d 829 (Cal. 1999).

11. Cal. Penal Code $\S 667$ (d)(3)(D) (Deering 1998).

12. See generally Franklin E. Zimring, The Common Thread: Diversion in Jivenile Justice, 88 CALIF. L. Rev. 2477 (2000) (describing the origin of juvenile justice as a way of diverting juveniles from criminal courts). 
formed, the early juvenile courts primarily sought to treat children through diversion and rehabilitation because juveniles were not considered to be at fault for their criminal behavior. ${ }^{13}$ Thus, the original premise of the juvenile court posited no conflict between the treatment of the child and the protection of society because society would be most protected by rehabilitating its young and preventing them from entering lives of crime. ${ }^{14}$ Moreover, to meet the specific rehabilitative needs of each child, the juvenile courts favored flexibility at the expense of formal processes. ${ }^{15}$ The courts acknowledged that adolescence was a transitional period, a time when children learn, usually by trial and error, to become adults. ${ }^{16}$ It followed that attaching permanent, irreversible consequences to youthful mistakes was inappropriate.

In California, except as otherwise provided by statute, the jurisdiction of the juvenile court extends to any person under eighteen years of age who violates the criminal law. ${ }^{17}$ An offender's entry into the juvenile justice system begins with intake-the screening process by police-after which a juvenile may either be released outright, released after an official record of the contact is made, or referred to the juvenile authorities for further action. ${ }^{18}$ If a youth is referred to the juvenile authorities, a probation officer meets with the child and any complaming witnesses. Then the officer decides whether to pursue the matter in court, refer the youth to other social service agencies, place the child on informal probation, or dismiss the case. ${ }^{19}$

Because the original juvenile court system included no formal criminal court procedures, there was no place for incorrigible young criminals. Young offenders deemed unamenable to rehabilitation have always been considered more appropriate for treatment outside the systein..$^{20}$ For these extreme cases, almost all juvenile court systems have long provided a

13. See Julianne P. Sheffer, Note, Serious and Habitual Offender Statutes: Reconciling Punishment and Rehabilitation Within the Juvenile Justice System, 48 VAND. L. REv. 479, 482 (1995). As one juvenile court judge explained, if the juvenile "is treading the path that leads to criminality," the role of the state is "to take him in charge, not so much to punish as to reform, not to dcgrade but to uplift, not to crush but to develop, not to make him a criminal but a worthy citizen." Julian W. Mack, The Juvenile Court, 23 HaRv. L. REv. 104, 107 (1909).

14. Miriam Van Waters, Youth in CONFlict 11 (1925).

15. See Franklin E. Zimring, The Changing Legal World of Adolescence 33 (1982) [hereinafter ADOLESCENCE].

16. See id. at 89-96.

17. CAL. Welf. \& INST. CODE $\$ 602$ (a) (Deering 1998).

18. Martin R. Gardner, Understanding Juvenile Law 246-47 (1997); see also Joyce Dougherty, Negotiating Justice in the Juvenile System: A Comparison of Adult Plea Bargaining and Juvenile Intake, 52 FED. PROBATION 72 (1988).

19. GARDNER, supra note 18 , at 246.

20. See David S. Tanenhaus, The Evolution of Transfer Out of the Juvenile Court, in THE Changing Borders of Juvenile Justice 13, 19-25 (Jeffrey Fagan \& Franklin E. Zimring eds., 2000); Robert O. Dawson, Judicial Waiver in Theory and Practice, in THE Changing Borders of Juvenile Justice 45, 45 (Jeffrey Fagan \& Franklin E. Zimring eds., 2000). 
mechanism by which qualifying juvenile offenders can be transferred to criminal courts so that the juvenile courts do not waste their resources in futile attempts to rehabilitate them. ${ }^{21}$

California transfer law provides that a mimor accused of a crime is subject to the juvenile court's jurisdiction unless he or she is either determined to be unfit for treatment under the juvenile court law or accused of certain serious crimes. ${ }^{22}$ For minors sixteen years of age or older, the prosecutor may file a motion to transfer the juvenile to criminal court. The motion triggers an investigation and report by the probation officer on which the court bases its determination of whether the youth is amenable to the care, treatment, and programs available through the juvenile court. The court's determination of fitness considers the minor's degree of criminal sophistication, whether the minor can be rehabilitated, the minor's prior delinquency history, the success of any previous attempts by the juvenile court to rehabilitate the minor, and the circumstances and gravity of the alleged offense. ${ }^{23}$ In addition, a minor fourteen years of age or older accused of one of a few listed, more serious crimes is presumed not to be a fit and proper subject for treatment in the juvenile court systen $1 .{ }^{24}$ The minor has a right to a fitness hearing, where he or she has the burden of rebutting the presumption of unfitness by a preponderance of the evidence. ${ }^{25}$

If the juvenile court expressly finds that the minor is not a fit and proper subject for treatment under juvenile court law, the prosecutor may file charges against the individual as an adult in criminal court, ${ }^{26}$ where the youth will be subject to the laws and protections applicable to adult criminal proceedings. ${ }^{27}$ If the child is convicted in criminal court, his or her record will contain a permanent, unsealed criminal conviction. Under the jurisdiction of the juvenile court, a finding that the juvenile committed the offense cannot result in a criminal conviction. ${ }^{28}$ Rather, the juvenile will be adjudged a delinquent and prescribed the treatment that the judge deeins

21. See ZmRrng, Adolescence, supra note 15, at 39 (quoting Juvenile Court of Cook County, ANN. REP. 123 (1907)).

All right-minded people are willing to have boys and girls have chances to do the right thing, but after they persistently throw chances away the same people would have a right to insist that these young people be really controlled, even if it takes the criminal court process to do it.

Id.

22. CAL. Welf. \& INST. CODE $\$ 707(a)$-(c) (Deering 1998).

23. Id. $\S 707(\mathrm{a})(1)$.

24. Id. \$ 707(b)-(c).

25. CAL. R. CT. 1483(a) (West 2002).

26. CAL. WELF. \& INST. CODE $\$ 707$ (a) (Deering 1998).

27. Id. $\S 707.1$ (a). See generally CAL. WeLF. \& INST. CODE $\S 602$ (Deering 1998).

28. Id. $\S 203$ ("An order adjudging a minor to be a ward of the juvenile court shall not be deemed a conviction of a crime for any purpose...."). 
appropriate. ${ }^{29}$ If the juvenile court wants to keep an eye on the child by imposing probation, for example, it must adjudge him or her a delinquent. ${ }^{30} \mathrm{~A}$ finding that the juvenile committed the alleged offenses "is a necessary precondition to a subsequent disposition, whether rehabilitative or punitive." ${ }^{31}$

The recent enactment of California's Proposition 21 amended California Welfare and Institutions Code sections 602 and 707(d) to broaden the range of possible circumstances in which prosecutors may transfer minors to criminal court and file criminal charges against minors fourteen years of age or older. ${ }^{32}$ Amended section 707(d) authorizes prosecutors to file charges directly in criminal court, without a judicial determination of unfitness in juvenile court, in three situations: (1) if a minor sixteen years of age or older is accused of an offense listed in California Welfare and 1nstitutions Code section $707(\mathrm{~b}) ;{ }^{33}$ (2) if a minor fourteen years of age or older is accused of certain serious offenses under specified circumstances; ${ }^{34}$ or (3) if a minor sixteen years of age or older with a previous juvenile adjudication for an offense committed at age fourteen or

29. See CAL. Welf. \& INST. CODE $\S \S 602,707$; GARdNer, supra note 18 , at 296 . For a discussion of sentencing dispositions in the juvenile court, sec Barry C. Feld, Jivenile and Criminal Justice Systems' Responses to Youth Violence, 24 CRIME \& JUST. 189, 220-25 (1998) and GARDNER, supra note 18, at 306-28. Disposition decisions take into account the juvenile's background, environment, health, family, and educational situation. The punitive options are confinement, probation (with an option to impose specific conditions), restitution, community servicc, or community-based institutionalization. GARDNER, supra at 305.

30. Probation, the most common juvenile court disposition, allows the child to remain at home but permits the judge to impose specific probation conditions tailored to the needs of each juvenile. Probation officers generally remain in regular contact with the child to ensure compliance with probationary conditions. GARDNER, supra note 18 , at 306.

31. Id. at 261.

32. California voters passed Proposition 21, "The Gang Violence and Juvenilc Prevention Act of 1998," on March 7, 2000.Proposition 21, approved by voters Primary Elec. (Mar. 7, 2000). The new law made several changes to the existing statutes governing minors accused of violating criminal laws. Manduley v. Superior Court, 41 P.3d 3, 11-12, 27-28 (Cal. 2002). The first several sections of the act deal with criminal gang activity. The next few sections amend Three Strikes to expand the list of crimes that constitute "serious" or "violent" felonies, which thus can count as prior strikes. Id. The rest of Proposition 2l modifies the procedures of the juvenile justice system by, among other things, expanding transfer, limiting the confidentiality of juvenile criminal records, restricting pre-hearing release, and revising procedural and evidentiary rules. $I d$. at 28 . For the amended law governing transfer, see CAL. WELF. \& INST. CODE $\$ \S 707(d), 602(b)$. The California Supreme Court recently upheld these provisions of Proposition 21 against various federal and state constitutional challenges. See Manduley, 41 P.3d at 8-9 (holding that Proposition 21 does not violate due process, equal protection, the separation of powers doctrine, or the single-subject requirement for initiatives).

33. CAL. WELF. \& INST. CODE $§ 707(d)$ (1) (Deering 1998). Section 707(b) includes offenses such as murder, robbery, and assault with a firearm. $I d$. $\$ 707(\mathrm{~b})$.

34. Id. $\$ 707$ (d)(2). Among the special circumstances are: commission of an offense that would be, if committed by an adult, punishable by death or life imprisonment; personal use of a firearm; and commission of a section 707(b) offense "for the benefit of, at the direction of, or in association with any criminal street gang." Id. 
older is accused of certain specified offenses. ${ }^{35}$ Proposition 21 also expanded the circumstances in which a prosecutor must file charges in criminal court. The provision now requires prosecution in criminal court for a slightly revised list of offenses and decreases the qualifying age from sixteen to fourteen. ${ }^{36}$

Transfer helps to preserve the rehabilitative ideal of the juvenile justice systein; those offenders who are truly deserving of punishment and are not amenable to treatment are exported to adult court. ${ }^{37}$ However, as juvenile offenders have coine to be viewed as adult criminals, ${ }^{38}$ state

35. CAL. WeLF, \& INST. CODE $\$ 707$ (d)(3) (Deering 1998). The three circumstances listed in $\$$ 707(d)(3) are: (A) any felony in which the victim was (1) elderly or (2) had one of several listed disabilities and the juvenile knew or reasonably should have known about the disability; (B) any felony "committed for the purposes of intimidating or interfering" with another person's constitutional rights because of that person's "race, color, religion, ancestry, national origin, disability, gender, or sexual orientation"; and (C) the offense was associated with, for the benefit of, or at the direction of any criminal street gang. Id. $\$ 707$ (d)(3)(A)-(C). In crimmal court, the mimor is entitled to a preliminary hearing to deternine whether "reasonable cause exists to believe" that the mimor coines within one of these circumstances under $\S 707$ (d). Id. $\$ 707$ (d)(4).

36. Id. $\S 602$ (b). Before Proposition 21, the law required offenders sixteen years of age or older who had a previous felony juvenile adjudication committed at fourteen years of age or older and whose current alleged offense was one of several enumerated serious offenses to be prosecuted in criminal court without any determimation of fitness by the juvenile court. CAL. WELF. \& INST. CODE $\$$ 602(b) (West 1999), amended by 1999 Cal. Stat. ch. 996, $\S 12.2$. The current version of $\S$ 602(b) includes murder, if personally committed by the minor under an alleged special circumstance, and certain sex offenses with an alleged special circumstance. $\$ 602(b)$.

37. For a discussion of the arguments for and against waiver, see Jennifer M. O'Connor \& Lucinda K. Treat, Getting Smart About Getting Tough: Juvenile Justice and the Possibility of Progressive Reform, 33 AM. CRIM. L. Rev. 1299, 1312-18 (1998).

38. Media representations of violent schoolchildren killing their classmates, reports of the increased rate of homicides committed by juveniles, scare-tactic campaigns surrounding proposals like the recently passed Proposition 2I im California, and predictions of a coming storm of "superpredators" have all helped fuel the rage to punish child offenders. See William J. BENNETT ET AL., BoDY Count: Moral Poverty ... And How to Win America's War Against Crime and Drugs 27 (1996); Franklin E. Zmining, American Youth Violence 4-6 (1998); Robert E. Shepherd, Jr., Film at Eleven: The News Media and Juvenile Crime, 18 QuinniPIAc L. Rev. 687, 692-95 (1999) (arguing that the media dedicates a disproportionate amount of their coverage to crime and delinquency and that a disproportionate amount of crime coverage is devoted to random, violent crimes even though most homicides are committed agamst family members or acquamtances); Robert E. Shepherd, Jr., How the Media Misrepresents Jivenile Policies, 12 CRm. Just. 37, 38-39 (1998); John J. Dilulio, Jr., The Coming of the Super-Predators, WKLY. STANDARD, Nov. 27, 1995, at 23. Characterizations of these offenders have branded them as a "new breed" of criminal capable of crimmal activity more vicious than that undertaken by previous generations. ZimRING, supra, at 6-7.

This public perception persists despite crime statistics indicating the opposite conclusion. See Ryan Pintado-Vertner, How is Juvenile Justice Served? Racially Biased System Just Sweeps Troubled Youths Under the Rug, S.F. Chron. Feb. 27, 2000, at Commentary 1 ("Young people have helped pull California's crime rate to its lowest point since the 1960s. But they don't get credit. Instead, politicians use fear and racial profiling to convince the public that many of the state's youth-the most diverse in California's history-are 'super-predators' waiting to attack."). For a challenge of the assumptions and distorted statistics on which the predictions of a "coming storm" of superpredators is based, see Franklin E. Zimring, The Youth Violence Epidemic: Myth or Reality?, 33 WAKE FOREST L. REV. 727, 728 (1998). See also Lara A. Bazelon, Note, Exploding the Superpredator Myth: Why Infancy is the Preadolescent's Best Defense in Jivenile Court, 75 N.Y.U. L. REv. 159 (2000). 
legislatures and juvenile courts have begun to accept punishment as a proper goal of the juvenile justice system. ${ }^{39}$

Nevertheless, while many states explicitly recognize the goal of punishment as part of the modern juvenile justice system, most states are still unwilling to abandon rehabilitation completely. ${ }^{40}$ As an example of the recent hybrid approach, California law now provides that

Minors under the jurisdiction of the juvenile court as a consequence of delinquent conduct shall, in conformity with the interests of public safety and protection, receive care, treatment, and guidance that is consistent with their best interest, that holds them accountable for their behavior, and that is appropriate for their circumstances. ${ }^{41}$

Although the statute allows punishment, that punishment must be "consistent with the rehabilitative objectives" of the juvenile justice system. ${ }^{42}$ Further, the California Welfare and Institutions Code now directs that "[j]uvenile courts and other public agencies charged with enforcing, interpreting, and administering the juvenile court law shall consider the safety and protection of the public, the importance of redressing injuries to victims, and the best interests of the minor in all deliberations pursuant to this chapter." ${ }^{43}$

Thus, despite acknowledging punitive goals, the jurisprudence of juvenile justice in California has not abandoned the notion that juvenile offenders are distinguishable from adult criminals. As a California Court of Appeal recently noted,

The purpose of juvenile proceedings remains markedly different from that of adult proceedings. The state's purpose in juvenile proceedings is a rehabilitative one distinguishable from the criminal justice system for adults, which has a purely punitive purpose separate from its rehabilitative goals .... While part of the juvenile justice system does include punishment in certain cases, it does not change the primary purpose of juvenile proceedings from that of preserving and promoting the welfare of the child. In

39. See GARDNER, supra note 18, at 185 ("[S]ome legislatures have adopted systems incorporating principles of personal responsibility and accountability, foreign to the traditional premises of juvenile justice, in order to give minors their 'just desserts."'); see also Candace Zierdt, The Little Engine that Arrived at the Wrong Station: How to Get Juvenile Justice Back on the Right Track, 33 U.S.F. L. REv. 401, 411 (1999); Sheffer, supra note 13, at 484-86.

40. See Sheffer, supra note 13 , at 482-84. Several juvenile codes now acknowledge other purposes, such as holding juveniles accountable, providing effective deterrents, protecting the public, and imposing punishments that are proportionate to the seriousness of the offense. U.S. DEP'T OF Justice, Office of Juvenile Justice and Delinquency Prevention, Juvenile Justice: A Century of Change, 1999 Nat'l Report Series 5 (1999).

41. CAL. Welf. \& INST. CODE $\S 202$ (b) (Deering 1998).

42. Id.

43. Id. § 202(d). 
juvenile law, "the reference to punishment did not alter the overall rehabilitative aspect of the juvenile justice system."

As the next section will argue, the punitive intent behind Three Strikes's harsh mandatory penalties is mconsistent with the rehabilitative goal that remains an explicit part of California's juvemile justice system.

II

\section{California's Three Strikes LaW: Using Juvenile Adjudications as Automatic PENALTy ENHANCEMENTS}

The passage of Three Strikes in 1994 set the stage for a collision between the rehabilitative and diversionary spirit of the juvenile justice system and the punitive imtent behind the legislation. ${ }^{45}$ Three Strikes singled out certain recidivists, including some whose only prior offenses were juvenile adjudications, and imposed harsh, mandatory penalties. Before the passage of Three Strikes, prior juvenile court adjudications could be used to enhance an offender's sentence, but they had not been used automatically to enhance sentences. ${ }^{46}$ Although juvenile adjudications are used, in some form, in adult court sentencing in every jurisdiction in the United States ${ }^{47}$ most other sentencing schemes give juvenile adjudications less weight than comparable adult convictions. ${ }^{48}$

44. In re Myresheia W., 72 Cal. Rptr. 2d 65, 68-69 (Cal Ct. App. 1998) (quoting In re Charles C., 232 Cal. App. 3d 952, 960 (1991)) (upholding the use of juvenile adjudications not tried in front of a jury as strikes).

45. Tonya K. Cole, Note, Counting Juvenile Adjudications as Strikes Under California's “Three Strikes" Law: An Undermining of the Separateness of the Adult and Juvenile Systems, 19 J. Juv. L. 335,335 (1998) ("California's three strikes law is an example of legislation in direct opposition to the rehabilitation goal and 'fresh start' promise of the juvenile court system.").

46. See Lisa Forquer, Comment, California's Three Strikes Law-Should a Juvenile Adjudication be a Ball or a Strike?, 32 SAN DIEGo L. REv. 1297, 1310-15 (1995) (explaining how juvenile adjudications and juvenile convictions were used in sentencing before Three Strikes). See generally Joseph B. Sanborn, Jr., Second-Class Justice, First-Class Punishment: The Use of Juvenile Records in Sentencing Adults, 81 Judicature 206, 208 (1998). Before Three Strikes, prior juvenile adjudications could only be considered as an aggravating factor in determining where, within the determinate sentencing range, the sentence should be set. Conduct underlying a juvenile adjudication could also be considered in a decision of whether or not to impose the death penalty. Id. Proposition 8, the Victims' Bill of Rights, allowed any convictions for prior felonies by a juvenile that resulted froin a criminal proceeding to be used to enhance sentences in subsequent criminal actions. CAL. PENAL CODE $\$ 667$ (Deering 1998).

47. See Sanbom, supra note 46 , at $209-10$. The fifty-two jurisdictions include the fifty states plus the District of Columbia as well as the federal criminal courts. Sanborn reports that forty-five jurisdictions have statutes stating that limitations on the use or disclosure of juvenile records in sentencing no longer apply once an offender has been convicted in criminal court; thirty-five jurisdictions have provisions, in the form of sentencing guidelmes, court rules, or presentence investigative reports, indicating that juvenile adjudications are significant factors at sentencing; and forty-five jurisdictions have caselaw upholding the use of juvenile adjudications as a factor at sentencing in criminal court. The only two states preventing juvenile records from being used for sentence enhancement, Arizona and Georgia, allow juvenile adjudications to render an offender ineligible for probation. Id. at 209. A 1995 survey showed that about half of the states systematically 


\section{A. Legislative History and the Passage of Three Strikes}

A primary motivation behind the passage of both the bill and the initiative was to curtail the discretionary power of judges, who were seen as the major culprits in the "revolving door" criminal justice system. ${ }^{49}$ Three Strikes was not simply about increasing the length of sentences; it aimed to ensure that the increased sentences would be applied with force. Thus, Three Strikes favored the discretion of the prosecutor, who was trusted by law-and-order advocates, over that of the judge..$^{50}$

Mike Reynolds, a political outsider who turned into a single-issue activist after his daughter was murdered by a repeat offender, drafted Three Strikes for placement on the ballot as a voter mitiative. ${ }^{51}$ In March 1994, the legislature passed Three Strikes without changing a word of Reynolds's draft. ${ }^{52}$ The threat of being labeled "soft on crime" deterred many legislators from taking a serious, visible stand against Three Strikes. ${ }^{53}$ Thus, Three Strikes sailed through the state legislature "without serious rational discourse or legislative compromise because of public panic, its chief proponent's distrust of politicians, judges and lawyers, and politicians' manipulation of public fear." ${ }^{254}$ There was little discussion of any of the

consider juvenile adjudications in determining adult sentences. NEAL MILLER, NAT'L INST. OF JUSTICE, State Laws on Prosecutors' and Judges' Use of Juvenile Records (1995).

48. Barry C. Feld, Juvenile and Criminal Justice Systems' Responses to Youth Violence, 24 CRIME \& JuST. 189, 214 (1998).

49. People v. Superior Court (Romero), 917 P.2d 628, 647 (Cal. 1996) ("Plainly the Three Strikes Initiative, as well as the legislative act embodying its terms, was intended to restrict courts' discretion in sentencing repeat offenders."); see also Luna, supra note 2, at 12-20; Wyman \& Schmidt, supra note 5 , at 254.

50. Zimring et al., Punishment and Democracy, supra note 4, at 26-27. The prosecutor alone can decide to reduce a current offense charge to a misdemeanor to circumvent the harsh penalties of Three Strikes. Id.; Malcolm M. Feeley \& Sam Kamin, The Effect of "Three Strikes and You're Out" on the Courts: Looking Back to See the Future, in THREe STRIKES AND You'Re OUT: Vengeance aS Public Pol.1CY 135, 150 (David Shichor \& Dale K. Sechrest eds., 1996) (stating that Three Strikes "has the effect of enlarging the discretionary powers-and hence sentencing powers-of the prosecutor at the expense of the judges."). Moreover, the statute explicitly grants prosecutors the discretion to dismiss prior strikes "in the furtherance of justice" or if there was insufficient evidence to prove the prior conviction. CAL. Penal Code $\$ 667(f)(2)$ (Deering 1998). In People v. Superior Court (Romero), 917 P.2d 628 (Cal. 1996), the California Supreme Court held that judges also have discretion to dismiss prior strikes in the interest of justice. See discussion infra Part II.C.

51. Dan Morain, A Father's Bittersweet Crusade, L.A. Times, Mar. 7, 1994, at Al.

52. Dan Morain, Proposition I84 "Three Strikes": A Steamroller Driven by One Man's Pain, L.A. Times, Oct. 17, 1994, at A1; Morain, supra note 51, at A1. The legislative version of Three Strikes is now codified in California Penal Code section 667(b) to (i). CAL. Penal Code $\$$ 667(b)-(i) (Deering 1998).

53. See generally Michael Vitiello, "Three Strikes" and the Romero Case: The Supreme Court Restores Demoeracy, 30 Loy. L.A. L. Rev. 1643, 1652 (1997) ("Three Strikes' passed as a result of public panic, flamed by politicians who spurned rational debate."). See also Michael Vitiello, Three Strikes, 87 J. Crum. L. \& Criminology 395, 413 (1997) [hereinafter Vitiello, Three Strikes] ("Reynolds was adept at using the press to intimidate those who raised questions about the legislation. Reynolds' judgment that a politician was soft on crime promised to be devastating.").

54. Vitiello, Three Strikes, supra note 53, at 410 (1997). 
major provisions of Three Strikes, and there was barely any mention at all of the juvenile adjudication provision, which was "the fine print" in a statute containing "big print" that "nobody seems to have." 55 The legislative history references juvenile adjudications, but the brief statements made by the senate and the assembly are inconsistent. ${ }^{56}$ Furthermore, the ballot pamphlet's explanation of the initiative version is inconsistent in defining which juvenile offenses count as strikes. ${ }^{57}$

After the passage of the legislative version of Three Strikes in March of 1994, Reynolds decided to continue his initiative campaign so voters could show their support for Three Strikes. ${ }^{58}$ In November 1994, 72\% of California voters approved Proposition 184, the initiative version of the ${ }$ law ${ }^{59}$ which was virtually identical to the legislature's version. ${ }^{60}$ The passage of Proposition 184 was not insignificant. The opportunity to vote on Three Strikes allowed California voters to send a strong public message that they supported the mandatory penalties. Three Strikes has since become virtually untouchable in the political branches of the California government, as evidenced by Governor Davis's veto of a bill asking for a study of the effects of Three Strikes. ${ }^{61}$

\section{B. Overview of the California Three Strikes Law}

The stated purpose of Three Strikes is "to ensure longer prison sentences and greater punishment for those who commit a felony and have

55. Franklin E. Zimring, Populism, Democratic Government, and the Decline of Expert Authority: Some Reflections on "Three Strikes" in California, 28 PAC. L.J. 243, 250-51 (1996).

56. The Senate Judiciary Committee's Analysis of this provision explained that it "would apply if the person was 16 or older when adjudicated, and the offense committed was from the list of offenses enumerated in Welfare \& Institutions Code section 707(b) or if it was a serious or violent offense." California Senate Judiciary Committee, Bill Analysis-A.B. 971, at 9, Feb. 17, 1994. In contrast, the assembly analysis restricts the list of qualifying juvemile prior offenses to exclude any violent or serious offenses that are not also listed in section 707(b). See California Assembly Committee on Public Safety, Bill Analysis-A.B. 971, at 2, Jan. 3, 1994.

57. California Ballot Pamphlet, General Election 33 (Nov. 8, 1994). The language in the first part of the description uses "convictions while a minor," suggesting it refers to criminal convictions at the exclusion of juvenile adjudications. The last sentence implies, however, that Three Strikes was clearly intended to make specified juvenile adjudications count as prior felony convictions for sentence-enhancement purposes. "These specified crimes generally include the same crimes defined as serious and violent felonies." $1 d$.

58. Morain, supra note 51.

59. ZimRing ET AL., PUNISHMENT AND DemocraCY, supra note 4, tbl. 1.1.

60. The mitiative version of Three Strikes is now codified as California Penal Code section 1170.12. Cal.PENAL Code $\$ 1170.12$ (Deering 1998).

61. Governor Gray Davis, Veto Attachment to S.B. 873, Oct. 10, 1999 (stating that "an additional... study is unlikely to produce much, if any, useful information that is not already available"). See also Rene Sanchez, A Movement Builds Against "Three Strikes" Law, Wash. Post, Feb. 18, 2000 at A3 (noting that the legislature has twice passed bills authorizing studies of Three Strikes, but Governors Pcte Wilson and Gray Davis each vctoed the bills); ZimRING ET AL., PUNISHMENT AND DEMOCRACY, supra note 4, at 222. 
been previously convicted of serious and/or violent felonies." ${ }^{92}$ The triggering offense may be any felony under California law, including a "wobbler" offense, when such an offense is charged and sentenced as a felony. ${ }^{63} \mathrm{~A}$ "wobbler" offense ${ }^{64}$ is an offense that can, at the discretion of the prosecutor, be charged as either a felony or a misdemeanor. ${ }^{65}$

\section{Definitions of Prior Strikes}

Not all felony offenses can count as prior strikes. The statute contains three subdivisions defining qualifying offenses. ${ }^{66}$ First, California Penal Code section $667(\mathrm{~d})(1)$ statcs that a prior strike includes "[a]ny offense in subdivision (c) of section 667.5 as a violent felony or any offense defined in subdivision (c) of section 1192.7 as a serious felony in this state. ${ }^{967}$ Second, California Penal Code section 667(d)(2) provides:

A conviction in another jurisdiction for an offense that, if committed in California, is punishable by imprisonment in the state prison. A prior conviction of a particular felony shall include a conviction in another jurisdiction for an offense that includes all of the elcments of the particular felony as defined im subdivision (c) of Section 667.5 or subdivision (c) of Section $1192.7 . .^{68}$

Lastly, certain juvenile adjudications can count as prior strikes. ${ }^{69}$ In contrast to the relatively simple and straightforward definitions of adult convictions and out-of-state convictions, the provision specifying the requirements for juvenile adjudications that qualify as strikes is complcx.

62. Cal. Penal Code $\S 667$ (b) (Deering 1998). It is important to recognize at the outset that Three Strikes did not create an entirely independent system of sentencing. Rather, it was simply laid on top of the existing criminal sentencing structure in California. Thus, it must interact with and be interpreted in light of the existing sentencing structures for both adult and juvenile offenders. The new penalty provisions were intended to coexist with the determinate sentencing system in place in California, including the Welfare and Institutions Code, which governs juvenile offenders. Although the provisions of Three Strikes change some elements of these systems for qualifying repeat offenders, these sentencing laws provide the basis for determining whether an offender qualifies for Three Strikes. Moreover, for a second-strike offender, these sentencing laws identify the base sentence.

63. See Cal. Penal Code $\S 667(\mathrm{e})(1)$, (2)(A) (Deering 1998); People v. Terry, 54 Cal. Rptr. 2d 769, 770-71 (Cal. Ct. App. 1996).

64. An example of a wobbler offense that may count as a third strike is petty theft with a prior, when charged and sentenced as a felony. CAL. PENAL CODE $\S 666$ (Deering 1998).

65. Andrade v. Att'y Gen. of Cal., 270 F.3d 743, 747 (9th Cir. 2001), cert. granted, 70 U.S.L.W. 3497 (U.S. Apr. 1, 2002) (No. 01-1127).

66. Cal. Penal Code $\S 667$ (d)(1)-(3) (Deering 1998).

67. Id. $\S 667(\mathrm{~d})(1)$. The combined list of violent and serious offenses contains many of the same offenses listed in California Welfare and Institutions Code section 707(b). See supra note 33 and accompanying text. Compare CAL. Penal Code $\S \S 667.5,1192.7$ (Deering 1998) with CAL. Welf. \& INST. CODE $\S 707$ (b) (Deering 1998). There are, however, soine offenses listed in $\S 707$ (b) that are not listed as serious or violent. And there are some serious or violent crimes missing from the list in $\$$ 707(b). See infra notes 70-74 and accoinpanying text.

68. Cal. Penal Code $\S 667(d)(2)$ (Deering 1998).

69. Id. $\S 667(\mathrm{~d})(3)$. 
Specifically, California Penal Code section 667(d)(3) lays out the following four required criteria for a juvenile adjudication to count as a prior strike:

(A) The juvenile was 16 years of age or older at the time he or she committed the prior offense;

(B) The prior offense is listed in subdivision (b) of Section 707 of the Welfare and Institutions Code or described in paragraph (1) [violent or serious felonies] $^{70}$ or (2) [out-of-state convictions for offenses that include all of the elements of violent or serious felomies in California] as a felony;

(C) The juvenile was found to be a fit and proper subject to be dealt with under the juvenile court law;

(D) The juvenile was adjudged a ward of the juvenile court within the meaning of Section 602 of the Welfare and Institutions Code because the person committed an offense listed in subdivision (b) of Section 707 of the Welfare and Institutions Code. $^{71}$

The first paragraph's age requirement is self-explanatory. Paragraph (B) requires that the prior offense be included in one of two sets of offenses: the Welfare and Institutions Code section 707(b) felony conviction may result froin a serious or violent offense under the California Penal Code or froin out-of-state convictions for offenses with the same eleinents as offenses characterized as serious or violent in California. ${ }^{72}$ There is some overlap between Welfare and Institutions Code section 707(b) and the Penal Code's list of serious and violent felonies, but each category imcludes some offenses not listed in the other group. Thus, offenses such as manufacturing controlled substances and escape from a juvenile hall, ${ }^{73}$ which are listed in section 707(b) but not categorized as serious or violent under the Penal Code, could count as strikes when committed by a juvenile, but not when committed by an adult. ${ }^{74}$ And soine serious or violent crimes, such as voluntary manslaughter and residential burglary, are not listed in section $707(\mathrm{~b}){ }^{75}$

70. Id. $\S 667.5$ (violent); id. $\S 1192.7$ (serious); see supra note 33-34.

71. Id.

72. Id. $\S 667.5$ (violent); id. § 1192.7 (serious).

73. Compare Cal. Welf. \& Inst. Code $§ 707$ (b) (Deering 1998), with Cal. Penal Code $\$ \$ 667.5$ and 1192.7 (Deering 1998). Other offenses listed in section 707 that are not on the list of serious or violent crimes include discharging a weapon in an inhabited building and dissuading a witness or suborning perjury. Id.

74. See CaL. Penal Code $\$ \S 667(d)(1)$, (3) (Deering 1998).

75. Compare Cal. Welf. \& Inst. Code $\S 707(b)$ (Deering 1998), with Cal. Penal Code $\$ \$ 667.5$ and 1192.7 (Deering 1998). Other serious or violent crimes that are not included in section 707 include rape not by force, violence, or threat of serious bodily harm; kidnapping a child under age fourteen; and a felony in which the child inflicts great bodily harm. See also CAL. PEnal Code $\S 667$ (d)(1) (Deering 1998) (referencing sections 667.5 and 1192.7). 
Paragraph (C)'s requirement that "[t]he juvenile was found to be a fit and proper subject to be dealt with under the juvenile court law"76 is similar to the language used in the statute governing transfer of minors to criminal court. Under Welfare and lnstitutions Code section 707(a), if the prosecutor moves for transfer and the juvenile court "find[s] that the minor is not a fit and proper subject to be dealt with under the juvenile court law," then the child may be transferred to criminal court. ${ }^{77}$ If the juvenile court instead concludes that the minor is a fit and proper subject for the juvenile court, it makes an express statement of this finding.

Paragraph (D) states that the juvenile court must have adjudged the minor a ward of the court, ${ }^{78}$ an action taken by the court when it concludes that the juvenile committed the alleged offense listed im Welfare and Institutions Code section 707(b) ${ }^{79}$ Paragraph (D) seems to limit strikeeligible juvenile adjudications to those for offenses listed in Welfare and Institutions Code section 707(b), in contrast to paragraph (B), which refers to offenses that the Penal Code lists as serious or violent. Thus, on its face, Three Strikes's juvenile adjudication provision seems to include two requirements that may be in conflict with each other.

\section{Three Strikes's Penalties}

Three Strikes's mandated penalties for defendants with prior strikes can dramatically increase the sentence for the current offense. Under the second-strike provision of Three Strikes, when a defendant with one prior strike is convicted of any felony, the court must sentence the defendant to a term twice as long as the sentence it would otherwise impose.$^{80}$ When a defendant with two or more prior strikes is convicted of a felony, the thirdstrike provision mandates a sentence of twenty-five years to life or three times the normal sentence to life, whichever is greater..$^{81}$ The statute also provides that sentenced offenders inust serve at least $80 \%$ of their sentence ${ }^{82}$ so a single strike on a felon's record can triple the time served for a conviction. The California Supreme Court has held that third-strike offenders are not eligible for parole until they have served at least a twenty-five year mandatory minimum term. ${ }^{83}$ Thus, a record containing two prior strikes can drastically increase the sentence for the current

76. Cal. Penal Code $\$ 667(d)(3)$ (C) (Deering 1998).

77. CAL. WeLf. \& INST. CODE $§ 707$ (a) (Deering 1998).

78. Cal. Penal Code $\S 602$ (a) (Deering 1998).

79. Id. $\S 667(\mathrm{~d})(3)(\mathrm{D})$.

80. Id. $\S 667(\mathrm{e})(1)$.

81. Id. $\S 667(\mathrm{e})(2)(\mathrm{A})$.

82. $\$ 667(c)(5)$.

83. In re Cervera, 16 P.3d 176 (Cal. 2001) (holding that a third-strike offender's mandatory minimum term of twenty-five years may not be reduced by good-time credits). 
offense, particularly for less serious offenses like larceny and possession of small amounts of drugs. ${ }^{84}$

\section{The California Supreme Court's Decision in Romero}

Because Three Strikes has been regarded as untouchable through legislative reform, the most significant method of curtailing its power has been through the "discretionary disuse of the law's provisions by prosecutors and judges." 85 This is a low-visibility, case-by-case process that is administered by trial courts and local prosecutorial offices. It is much harder for the state's highest court to impose public limits on Three Strikes in high-visibility litigation. The California Supreme Court justices face two important obstacles in any effort to limit the effect of Three Strikes: the symbolic importance of the overwhelming passage of an mitiative motivated by popular distrust of the judiciary ${ }^{86}$ and the danger of being removed from the court in a retention election. ${ }^{87}$

84. For example, the offense of petty theft with a prior is ordinarily punishable by up to one year in jail, if charged and sentenced as a inisdemeanor, and up to three years in prison, if charged and sentenced as a felony. CAL. Penal Code $\$ \S 18,666$. With two prior strikes, however, a petty theft offender with a prior theft offense can receive a prior sentence of twenty-five years to life, with no parole eligibility for at least twenty-five years. CAL. Penal Code $\$ 667(\mathrm{e})(1)$.

85. Zimring et Al., PUnishment AND Democracy, supra note 4, at 126, 128-33.

86. The California Supreme Court, however, has claimed that it has a "solemn duty to 'jealously guard' the initiative process, it being "one of the most precious rights of our democratic process."” Amador Valley Joint Union High Sch. Dist. v. State Bd. of Equalization, 583 P.2d 1281, 1302 (Cal. 1978) (quoting Associated Hoine Builders etc., Inc. v. City of Livermore, 557 P.2d 473, 477 (Cal. 1976)). See also Philip L. Dubois \& Floyd Feeney, Lawmaking by Initiative: Issues, Opinions, AND COMPARISONS 44-45 (1998) (noting the view that judges "are reluctant to overturn measures recently approved by the voters, and therefore strain to find such measures constitutional.").

87. Robert S. Thompson, Judicial Retention Elections and Judicial Method: A Retrospective on the California Retention Election of 1986,61 S. CAL. L. Rev. 2007, 2018 (1988). In 1986, Chief Justice Rose Bird and two other justices, Cruz Reynoso and Joseph Grodin, were rennoved by the voters of California. John T. Wold \& John H. Culver, The Defeat of the California Justices: the Campaign, the Electorate, and the Issue of Judicial Accountability, 70 Judicature 348, 349 (1987). The 1986 retention election had two lasting effects on the court, especially in the realın of criminal justice. Their lenient handling of criminal justice cases was the primary complamt against the ousted justices. Zimring et al., Punishment and Democracy, supra note 4, at 129; John H. Culver, The Transformation of the California Supreme Court: 1977-1997, 61 ALB. L. REv. 1461, 1463 (1998). First, over a short period of time, the composition of the court shifted dramatically toward law-andorder conservatives because of three new appointunents by tough-on-crime Governors Deukmejian and Wilson. See Thompson, supra note 87, at 2018. Second, the justiccs became acutely aware of the potential consequences of deciding cases contrary to popular views of criminal justice. ZIMRING ET AL., Punishment AND Democracy, supra note 4, at 128-29. Former Justice Otto Kaus, who was not among the members of the court ousted in 1986, explained that "[ $t]$ here's no way a judge is going to be able to ignore the political consequences of certain decisions.... That would be like ignoring a crocodile in your bathtub." Paul Reidinger, The Politics of Judging, 52 A.B.A. J. 52, 58 (1987). Ousted Justice Joseph Grodin said after the retention election, "[i]t is one thing... for a court to tell a legislature that a statute it has adopted is unconstitutional; to tell that to the people of a state who indicated their direct support for the measure through the ballot is another." DuBols \& FEENEY, supra note 86, at 45 (quoting JosepH Grodin, IN PuRsurt of Justice 105 (1989)). Former Justice Kaus admitted that he "found it totally impossible to work on cases dealing with Prop 8 and not have im 
Despite the pressure to enforce Three Strikes rigorously, however, the California Supreme Court has taken a few significant steps toward weakening the mandatory nature of the law. ${ }^{88}$ The most significant and potentially broadly sweeping decision in this regard was People v. Superior Court (Romero), ${ }^{89}$ which held that judges have the power to dismiss prior strikes "in furtherance of justice." ${ }^{90}$ Although Three Strikes provides that prosecutors may dismiss prior strikes "in the furtherance of justice" or "if there is insufficient evidence to prove the prior conviction," the statute refers only to insufficient evidence in describing when a court may dismiss a prior strike. ${ }^{91}$ Despite this specific statutory language and its drafters' intent, the supreme court held that judges retain the power under Penal Code section 1385(a) to decide that a prior strike should be ignored in the interests of justice. ${ }^{92}$

mind, to some extent, that [his] retention depended on that vote." Bill Blum, Toward A Radical Middle, 77 A.B.A. J. 48, 52 (1991). These two factors had a dramatic effect on the court's handling of criminal, and especially death penalty, cases. The succeeding Lucas court did not reverse the direction that the supreme court had taken under Chief Justice Bird, other than in the field of criminal law. Culver, supra, at 1476-77. "Most conspicuously, the Lucas Court embraced a decidedly pro-victim, pro-prosecution, and pro-capital punishment stance in crininal law in contrast to the Bird Court." Id. at 1477. The Bird Court upheld only 4 of the 71 death penalty sentences it reviewed on automatic appeal between 1977 and 1986, whereas the Lucas Court, between 1987 and late-1995, upheld $85 \%$ of the 212 death penalty convictions it reviewed. Id. at 1486. See also Sam Kamin, Death and Distrust in California: On the Politics of Judging (2000) (unpublished Ph.D. dissertation, University of California, Berkeley) (on file with author).

88. Sanchez, supra note 61 ("Every proposal introduced in the state legislature to limit the use of three-strikes sentences has been blocked. ... So far, only California's Supreme Court has taken steps to limit three strikes....").

89. 917 P.2d 628 (Cal. 1996).

90. Id. at 630 .

91. Cal. Penal Code $\S 667(f)(2)$ (Deering 1998). The Three Strikes provision at issue in Romero states:

The prosecuting attorney may nove to dismiss or strike a prior felony conviction allegation in the furtherance of justice pursuant to section 1385, or if there is insufficient evidence to prove the prior conviction. If upon the satisfaction of the court there is insufficient evidence to prove the prior felony conviction, the court may dismiss or strike the allegation.

Id.

92. Cal. Penal Code $\S 1385$ (a) (Deering 1998) (authorizing a trial court to dismiss a criminal action "in furtherance of justice" on its own motion); Romero, 917 P.2d at 630. The supreme court previously held that the power to dismiss an action includes the lesser power to strike factual allegations relevant to sentencing, including allegations of prior felony convictions. Id. at 632 (citing People v. Tenorio, 473 P.2d 993 (Cal. 1970)). Section 1385 specifically provides that it "does not authorize a judge to strike any prior conviction of a serious felony for purposes of enhancement of a sentence under Section 667." CaL. PENal Code $\$ 1385$ (b) (Deering 1998). The State argued in Romero that this section expressly prohibits a court from using section 1385(a) to strike a prior felony allegation in Three Strikes cases. Romero, 917 P.2d at 636. The court rejected this argument and concluded that it was reasonable to distinguish between the judge's discretion in regular sentence enhancement under section 667 and a Three Strikes penalty. Id. at 647 . The court reasoned that the decision to place Three Strikes within section 667 did not provide the necessary "clear legislative direction" to strip courts of their power to dismiss prior felony allegations on their own motion. Id. at 646. 
As the Romero decision's restoration of judicial power demonstrates, the current court may be less influenced by the prospect of retention elections now that some time has passed since three supreme court justices were ousted in $1986 .{ }^{93}$ Nevertheless, unpopular decisions may still leave justices vulnerable. Because Romero's holding ${ }^{94}$ was perceived as signiflcantly weakening Three Strikes, ${ }^{95}$ conservative lawmakers threatened to lead a campaign supporting the ouster of four justices up for retention in the 1998 election. ${ }^{96}$ Thus, many observers are not as quick to ignore the looining threat of failing to survive a retention election. ${ }^{97}$

Romero has a potentially immense practical impact. First, trial judges can use Romero to overcome the harsh effects of Three Strikes provisions and to temper, at least im individual cases, the impact of decisions that interpret Three Strikes broadly. ${ }^{98}$ Under Romero, the judge's power to dismiss a strike "in furtherance of justice" is broad but "by no means absolute." 99 Romero concluded that the standard "requires consideration both of the constitutional rights of the defendant, and the interests of society represented by the People, in determining whether there should be a dismissal. At the very least, the reason for dismissal must be that which would motivate a reasonable judge." 100 The court cited as an abuse of discretion a dismissal based solely on "personal antipathy for the effect that the Three Strikes law would have on [a] defendant, while ignoring defendant's background, the nature of his present offenses, and other individualized considerations." ${ }^{101}$ In a later case, the supreme court explained that the courts "must consider whether, in light of the nature and circumstances of his present felomies and prior serious and/or violent felony convictions, and the particulars of his background, character, and prospects, the defendant may be deemed outside the scheme's spirit, in

93. See Culver, supra note 87 , at 1490 . Culver argues that "[ $t]$ he California Supreme Court has recovered from the internal turmoil and publie criticisin of two decades ago. Although some controversial decisions of the court will be denounced by one group or another, the court's institutional reputation is sound." Id.

94. 917 P.2d at 630.

95. Culver, supra note 87 , at 1490.

96. Id.

97. See, e.g., ZimRing ET AL., PUNISHMENT AND DemocracY, supra note 4, at 129 ("If ever a successful challenge to a Three Strikes law would seem to be a difficult proposition before a state supreme court, California in the 1990 s seems to be the place.").

98. Id. at 131-32; see also Clay M. Smith, The Missing Piece in the Three-Strikes Puzzle, 44 ORANGe County Lawyer 36, 39 (Feb. 2002) (arguing that Romero could appease those on both sides of the Three Strikes debate by allowing the law to retain its current structure while providing a "clear and existing legal basis for a trial court to avoid an unfairly harsh sentencing result"); People v. Garcia, 976 P.2d 831, 840-41 (Brown, J., dissenting) ("[U]nless carefully circumscribed," Romero "carries with it the real potential for undermining the intent of the Three Strikes law itself-namely, to restrict courts' discretion in sentencing repeat offenders.") (imternal citations and quotation marks omitted).

99. Romero, 917 P.2d at 648.

100. Id. (internal quotation marks and citations omitted).

101. Id. (internal quotation marks omitted). 
whole or in part ...."102 Thus, Romero allows judges to individualize sentencing determinations where Three Strikes penalties would otherwise have been mandatory. ${ }^{103}$

In addition, once Romero armed trial judges with the power to dismiss prior strikes, appellate judges could broadly interpret Three Strikes without necessarily leading to harsh results in individual cases. Perhaps appellate courts believe that trial courts' newfound discretion now politically requires appellate-level restraint. Decisions such as People v. Benson, ${ }^{104}$ which allowed a single incident to count as two strikes, were perhaps only palatable in light of Romero. While ardent supporters of tough-on-crime laws may be placated by opinions adopting broad interpretations of Three Strikes, individual application of judicial discretion can relieve many individuals from the harsh consequences of the supreme court's rulmgs. ${ }^{105}$

The factors outlined above-the ambivalent jurisprudence of California's juvenile justice system, the motivation behind and the impact of Three Strikes's overwhelming passage, the threat of retention elections, and the practical impact of the Romero decision-are critical to an understanding of the California Supreme Court's decisions in the two cases it has heard involving the juvenile adjudication provision of Three Strikes. These two decisions illustrate the tension between punishment and rehabilitation within the juvenile justice system itself and how that conflict has been exacerbated by the extension of the harsh punitive intent of Three Strikes to prior juvenile adjudications.

\section{III \\ The California Supreme Court's Three Strikes Decisions REgarding JUVENILE ADJUdiCATIONS}

\section{A. People v. Davis: Punitive Intent Triumphs}

When Three Strikes was discussed in the legislature, lawmakers expressed some uncertainty about whether the law should include prior juvenile court adjudications or only those juvenile convictions resulting from criminal court trials. ${ }^{106}$ The Senate Judiciary Committee expressed concern that the diminished due process protections available in juvenile court

102. People v. Williams, 948 P.2d 429, 437 (Cal. 1998).

103. See People v. McGlothin, 79 Cal. Rptr. 2d 83, 88 (Cal. Ct. App. 1998) (explaining that Romero "allows the court to perform its obligation to tailor a given sentence to suit the individual defendant"). Trial courts can selectively strike some prior strikes and leave the defendant's other strikes intact because the supreme court has held that it is not an abuse of discretion to strike one qualifying prior offense but not others. People v. Garcia, 976 P.2d 831, 839 (Cal. 1999) (affirming dismissal of one of the prior strikes because the defendant's criminal history was not violent and prior offenses were committed during a single period of aberrant behavior).

104. 954 P.2d 557 (Cal. 1998).

105. Zimring et al., Punishment and Democracy, supra note 4, at 131-32.

106. Mary Curtius \& Dan Morain, Jivenile Felonies Can Now Count Toward 3 Strikes, L.A. Times, July 4, 1997, at A1. 
would render the juvenile adjudication provision unconstitutional. ${ }^{107}$ Although some concerns were raised, the lack of serious debate about Three Strikes prevented lawmakers from resolving these issues before its passage. During the first couple of years that Three Strikes was in effect, many prosecutors declined to charge as strikes those juvenile offenses that failed to include an express finding of fitness. ${ }^{108}$ The Judicial Council of California initially recommended that trial judges refrain from using juvenile adjudications as strikes because of constitutional concerns. ${ }^{109}$ it was under this cloud of controversy and uncertainty that, in 1997, the California Supreme Court faced its first difficult decision regarding the scope of juvenile adjudications that could qualify as strikes under section $667(d)(3) .{ }^{110}$

\section{The California Supreme Court's Analysis}

In 1997, in People v. Davis, ${ }^{11}$ the California Supreme Court upheld the use of juvenile adjudications as strikes and examined one of the provision's four requirements for the first time. ${ }^{112}$ Specifically, the court interpreted California Penal Code section 667(d)(3)(C), which requires that "the juvenile was found to be a fit and proper subject to be dealt with under the juvenile court law." 113 lt found that an implied finding of fitness, present in every juvenile adjudication, met the requirement set out in paragraph (C).

Davis, charged with one count of murder and one count of atteinpted murder, had three prior offenses that were potential strikes. Two of the offenses were juvenile adjudications, one for felony assault and one for residential burglary, and the third offense was an adult conviction for robbery. ${ }^{114}$ The trial court granted Davis's motion to dismiss his two prior

107. Califormia Senate Judiciary Committee, Bill Analysis-A.B. 971, at 10, Feb. 17, 1994.

108. Curtius \& Morain, supra note 106.

109. Walter L. Gordon IIl, California's Three Strikes Law: Tyranny of the Majority, 20 WHITtIER L. Rev. 577, 598 (1999). In People v. Daniels, 59 Cal. Rptr. 2d 395 (Cal. Ct. App. 1996), the court of appeal held that expungement of prior juvenile convictions did not prevent their use as prior strikes in subsequent criminal proceedings. $1 d$. at 397 . The opinion does not mention the provision in Three Strikes that allows juvenile adjudications to count as strikes. See id. at 395-400.

110. Cal. Penal Code $\S 667$ (d)(3) (Deering 1998). For the full provision, see supra text accompanying note 71. For a discussion of the potential confusion of section 667(d)(3)'s language, see Forquer, supra note 46 (arguing that traditional principles of statutory construction support limiting strikes to those juvenile adjudications listed in Califomia Welfare \& lustitutions Code section 707(b)).

111. 938 P.2d 938 (Cal. 1997).

112. Although Davis was the first case before the supreme court where the offender's prior strikes included juvenile adjudications, there was no discussion of whether juvenile adjudications could be used as strikes in a third-strike proceeding. The court cited People v. Hazelton, 926 P.2d 423 (Cal. 1996), for the proposition that both out-of-state convictions and certain juvenile adjudications may count as strikes. Davis, 938 P.2d at 940 . Hazelton discussed only the interpretation of the provision dealing with out-of-state convictions as strikes, not the provision governing juvenile adjudications. See Hazelton, 926 P.2d at 424-28.

113. Cal. Penal Code $\$ 667(d)(3)(C)$ (Deering 1998).

114. Davis, 938 P.2d at $939-40$. 
juvenile adjudications, and the State appealed. ${ }^{115}$ Meanwhile, Davis was convicted of murder and sentenced to thirty-five years to life with a consecutive term of life plus five years. The court of appeal affirmed Davis's convictions and the order dismissing the prior juvenile adjudication for residential burglary, but it reversed the order dismissing the felony-assault adjudication as a strike. ${ }^{116}$ The California Supreme Court granted the petitions for review filed by both Davis and the State. ${ }^{117}$

In the supreme court, Davis argued that neither of his juvenile adjudications met the requirement of section $667(\mathrm{~d})(3)(\mathrm{C})$ that the juvenile be "found to be a fit and proper subject to be dealt with under the juvenile court law." 118 In neither of Davis's juvenile adjudication proceedings did the prosecutor move for a transfer to criminal court, so the juvenile court never held a hearing in which it expressly determined that Davis was a fit and proper subject for the juvenile court. The court held that paragraph (C)'s requirement that the juvenile "was found" fit for the juvenile court is met by an implied finding of fitness, which the court deemed present in every juvenile adjudication. ${ }^{119}$ The court was unwilling to restrict Three Strikes's application to those cases in which the juvenile court had made an express finding of fitness, as that would occur only if a prosecutor's inotion to transfer the juvenile to criminal court was denied. ${ }^{120}$ If the prosecutor had never moved to transfer the juvenile, the proceeding would have continued in the juvenile court, with no express finding of fitness.

Davis also argued that a juvenile adjudication for residential burglary should not be counted as a strike because, although it is a serious felony and satisfies the requirement of paragraph (B) of California Penal Code section $667(d)(3)$, it was not listed under Welfare and Institutions Code section $707(\mathrm{~b})$ as required by paragraph (D) of Penal Code section 667(d)(3). ${ }^{121}$ Davis's adult conviction and his juvenile adjudication for felony assault together constituted two prior strikes, which were enough to trigger Three Strikes's mandatory penalties. Thus, the court chose not to address the seeming conflict between paragraphs (B) and (D) of section 667(d)(3), and it left the residential burglary issue "for another day."122

The court prefaced its discussion with the declaration that "[t]he statute's unambiguous purpose is to provide greater punishment for recidivists." ${ }^{\text {"23 }}$ Because the language of the statute required a "finding" and

115. Id. at 939.

116. Id.

117. Id.

118. People v. Davis, 52 Cal. Rptr. 2d 241, 243 (Cal. Ct. App. 1996).

119. Davis, 938 P.2d at 939.

120. Cal. Welf. \& INST. Code $\S 602,707$ (a) (Deering 1998).

121. Id.

122. Davis, 938 P.2d at 942 . The issue left "for another day" in Davis is the issue discussed in People v. Garcia, 980 P.2d 829 (Cal. 1999), discussed infra Part IlI.B.

123. Davis, 938 P.2d at 940. 
not an "express finding," the court concluded that "nothing in the subdivision's language precludes inclusion of implied as well as express findings of fitness." 124 Although the language mcludes those cases im which a section 707 petition to transfer the juvenile was denied, "[i]t also reasonably includes the situation where the prosecutor does not file a... [section] 707 petition." 125 The court explained that interpreting the statute to require an express finding "would so severely limit those juvenile adjudications that would qualify as 'strikes' that such a result would seem to be at odds with the intent of [Three Strikes]."126

Reasoning that an implied finding-of-fitness requirement could help distinguish those cases that remain in juvenile court from those transferred to criminal court, the court did not consider paragraph (C) meaningless simply because every juvenile adjudication includes an implied finding of fitness. ${ }^{127}$ The court stated that "the presence of some duplication in a multiprong statutory test does not autoinatically render it meaningless." 128 Moreover, the court concluded that if the subdivision were interpreted as requiring an express finding, the age requirement for juveniles would have been superfluous. ${ }^{129}$ The court explained that at the time Three Strikes was written, prosecutors could move to transfer only minors sixteen years of age or older, so no juvenile under sixteen years of age would have an express finding of fitness. Thus, the court chose the interpretation that it deenied "the inore reasonable." 130

Justice Kennard's dissent, however, disputed the majority's reasoning regarding the age requirement. Although the law at the time the Three Strikes bill passed allowed a section 707 transfer petition only for juveniles sixteen years of age or older, a proposed change in the law, which took effect six months later, permitted some children as young as fourteen to be tried as adults. ${ }^{131}$

The court also defended its interpretation on constitutional grounds, based on the assumption that an express finding-or-fitness requirement would create differences in punishment that "would depend solely on an unsuccessful motion for a determination that the minor is unfit for treatment in the juvenile court system."132 The court found this to be an irrational distinction that the legislature could not have intended because it

124. Id. at 941 .

125. Id.

126. Id.

127. Id. at $941-42$.

128. Id. at 941 .

129. Id.

130. Id. at 942 .

131. Id. at 949 (Kennard, J., dissenting).

132. Id. at 941 . 
would raise issues of equal protection, due process, and separation of powers. ${ }^{133}$

Justice Mosk's dissent in Davis recognized a legislative intent to distinguish juvenile adjudications, reading the provision to require an express finding of fitness. ${ }^{134} \mathrm{He}$ made it clear that the court may not "assess the specific means that [the legislature] has chosen-which include the requirement of a finding of fitness." ${ }^{135}$ Justice Kennard similarly criticized the majority: "A court construing a statute, however, can never be guided by public sentiment alone .... [I]t is not enough to say that because the Legislature and the electorate wished to impose tougher penalties on repeat violent offenders, we should therefore give that enactment the harshest possible construction." 136

\section{A Four-Part Critique of Davis}

The Davis decision not only provided the supreme court's endorsement for using juvenile adjudications as strikes, it also eliminated one of the restrictions narrowing the set of juvenile offenses that may be charged as prior strikes. ${ }^{137}$ The Davis court, by allowing get-tough intent to prevail over other reasoned principles of justice and rehabilitation, failed in four ways to render an appropriate decision. First, the court failed to recognize obvious distinctions in Three Strikes between the treatment of juvenile adjudications and the treatment of other prior strikes. Second, the court ignored Three Strikes's intent to elevate the discretion of the prosecutor. Third, the court's interpretation represents the derogation of juvenile court authority because it refuses to recognize the weight that should have been given to the view of the juvenile court prosecutor. Lastly, the court ignored well-established principles of statutory interpretation.

\section{a. The Court Ignored Obvious Distinctions in the Statute}

Although in Davis the California Supreme Court was facing its first Three Strikes case in which the prior strikes consisted of juvenile adjudications rather than adult convictions, the decision "appeared to be" based on "statutory construction... which did not expressly address the constitutionality of using prior juvenile adjudications, nor its conflict with the rehabilitation goal of the juvenile court."138 The court simply referred to the unambiguous punitive purpose of the statute aimed at recidivists and refused to explore the issue of juvenile adjudications, perhaps because such

133. Id.

134. Id. at $943-44$ (Mosk, J., dissenting).

135. Id. at 943 .

136. Id. at 949 (Kennard, J., dissenting).

137. See Curtius \& Morain, supra note 106. One California prosecutor remarked that "[Davis] will open the floodgates to a massive number of strikes that weren't charged before." Id. at A32.

138. Cole, supra note 45 , at 341 . 
a discussion would have forced the court to distinguish the juvenile system from the criminal justice system. An acknowledgment of the distinct nature of the juvenile system may have compelled the court to recognize Three Strikes's inherent conflict with juvenile justice's fundamental rehabilitative and diversionary goals. Had the court confronted this tension, it may have been forced to reach the logical conclusion that the restrictions on the scope of juvenile adjudications need not mirror those placed on criminal convictions. Using juvenile adjudications as automatic enhancements contradicts the original conception of juvenile justice, which stressed that juveniles are not culpable for their crimes. ${ }^{139}$ It also raises due process concerns because juveniles in California have no right to a jury trial. ${ }^{140} \mathrm{~A}$ juvenile could be mistakenly adjudged a delinquent, ${ }^{141}$ attaching permanent punitive consequences without the benefit of a trial by jury. ${ }^{142}$ Nevertheless, the California Supreme Court upheld the use of juvenile adjudications as strikes without any acknowledgement that it was attaching permanent criminal consequences to a nonjury proceeding.

Rather than explore the appropriateness of counting juvenile adjudications as strikes, the court simply cited People v. Hazelton ${ }^{143}$ and took that proposition as given. ${ }^{144}$ The issue in Hazelton was whether, under the initiative version of Three Strikes, an out-of-state conviction counted as a strike in a third-strike proceeding. The court held that it did. ${ }^{145}$ The

139. Sanborn, supra note 46, at 206.

140. For a discussion of due process issues, see generally David Dormont, Note, For the Good of the Adult: An Examination of the Constitutionality of Using Prior Juvenile Adjudications to Enhance Adult Sentences, 75 MinN. L. REv. 1769 (1991); Luna, supra note 2, at 78-79. See also People v. Superior Court (Carl W.), 539 P.2d 807, 809 (Cal. 1975) ("[N]either the state nor the federal Constitution guarantees a jury trial in a juvenile proceeding."). A California court of appeal has revisited this issue when juvenile adjudications are used as strikes and concluded that nonjury juvenile adjudications can count as strikes. In re Myresheia W., 72 Cal. Rptr. 2d 65, 69 (Cal. Ct. App. 1998) ("Even considering the Three Strikes potential, the end result of a declaration of delinquency remains different from a finding of criminal guilt in adult proceedings."); see also People v. Fowler, 84 Cal.Rptr.2d 874, 877-78 (Cal. Ct. App. 1999) (finding that the fact that defendant was neither afforded nor waived a jury trial at the prior juvenile adjudication proceeding does not prevent use of that adjudication as a strike).

141. Martin Guggenheim and Randy Hertz, Reflections on Judges, Juries, and Justice: Ensuring the Fairness of Juvenile Delinquency Trials, 33 WAKE FoREst L. REv. 553, 556 (1998) (suggesting that "juries are generally more likely than judges to be fair and just triers of fact on the issue of guilt or innocence in a criminal delinquency case.") see also id. at 564-65 (citing examples of cases in which juveniles were adjudicated delinquent on scant evidence falling far short of the standard of beyond a reasonable doubt).

142. See David C. Owen, Striking Out Juveniles: A Reexamination of the Right to a Jury Trial in Light of California's Three Strikes' Legislation, 29 U.C. DAvIS L. REv. 437, 458 (1996) (arguing that juveniles should be given a right to jury trials because Three Strikes attached punitive consequences to juvenile adjudications).

143. 926 P.2d 423 (Cal. 1996).

144. See People v. Davis, 938 P.2d 938, 940 (Cal. 1997).

145. The language of the initiative version of Three Strikes differs from the legislative version on this point. See Hazelton, 926 P.2d at 424. Specifically, the legislative version refers back to all three paragraphs that define "strikes" for third-strike proceedings. See CAL. PENAL CoDE $§ 667(e)(2)(A)$ 
Hazelton holding applied only to out-of-state convictions, although the court did mention juvenile adjudications in its discussion. ${ }^{146}$ The Hazelton court relied on the fact that there was "no evidence in the legislative history that the voters intended to exclude out-of-state convictions from the purview of the initiative's third strike penalty."147

The court's reasoning in Hazelton should not extend to juvenile adjudications, however, because the drafters of Three Strikes likely intended to treat juvenile adjudications differently than adult convictions. A cursory look at the provisions of Three Strikes shows that the drafters did not intend the sphere of qualifying juvenile adjudications to be coextensive with the scope of qualifying criminal convictions. Furthermore, the requirements that qualify juvenile adjudications as strikes limit the scope of juvenile adjudications as compared to adult convictions, and these additional limitations must have been intended to narrow the scope of adjudications that may constitute strikes. The complexity of the four-prong test defining eligible juvenile adjudications starkly contrasts the simple requirement that prior adult convictions be serious or violent. ${ }^{148}$

It is entirely rational to conclude that the drafters of the Three Strikes initiative did not intend to impose a mandatory twenty-five-years-to-life sentence on a first-time felon who had two prior juvenile adjudications. This reading is consistent with the intent of the initiative to provide greater punishment for recidivists who were previously convicted of serious or violent felonies. ${ }^{149}$ Justice Mosk's concurrence in Hazelton noted that the rationale for out-of-state convictions did not extend to juvenile offenses because "the exclusion of juvenile adjudications is not irrational; generally, the underlying proceedings are deemed not to be criminal in nature." 150 Thus, the court's application of Hazelton in Davis ignored the obvious distinctions in the statute between adult convictions and juvenile adjudications.

\section{b. The Court Ignored the Link Between an Express-Finding Requirement and the Legislative Intent to Elevate the Discretion of the Prosecutor}

The Davis court's reading of the statute violates the intention behind Three Strikes to ensure the primacy of prosecutorial discretion. Three Strikes was the first time that California allowed juvenile adjudications to

(Deering 1998). In contrast, the initiative version refers back to only the first paragraph, including California convictions for serious or violent felonies but not including out-of-state convictions or juvenile adjudications. See CaL. Penal Code $\S 1170.12$ (c)(2)(A) (Deering 1998). The court concluded that despite the difference, interpreting the initiative version to include out-of-state convictions as strikes in third-strike proceedings is "consistent with the statutory scheme." Hazelton, 926 P.2d at 427.

146. Hazelton, 926 P.2d. at 426.

147. Id. at 427.

148. See Cal. Penal Code $\S 667$ (d)(1)-(3) (Deering 1998).

149. See Cal. Penal Code $\S 667$ (b) (Deering 1998).

150. Hazelton, 926 P.2d at 431 (Mosk, J., concurring). 
be used as automatic sentence enhancements. ${ }^{151}$ The legislature may well have intended to transform only a small set of juvenile adjudications into automatic sentencing enhancements. And the legislature may reasonably have intended that set to include those adjudications that the prosecutor considered the most serious, as indicated by the prosecutor's motion to declare the juvenile unfit to be dealt with in juvemile court. Still, the Davis court stated that the legislature could not have intended to severely limit the number of juvemile adjudications that could count as strikes.

If even the prosecutor does not consider the offense serious enough to warrant a motion for transfer based on the offender's history, past and expected future success of rehabilitation, and the circumstances and gravity of the offense, ${ }^{152}$ it would seein fair to conclude that the juvenile does not deserve lifelong punitive consequences for the offense. ${ }^{153}$ If the prosecutor's inotion is successful, the juvenile will be tried in adult court where a conviction will count as a strike. If the motion is unsuccessful, the juvenile remains in the juvenile court with an express finding of fitness, but it is now clear that the prosecutor considered the offense to be of a serious nature. ${ }^{154}$ Thus, the application of Three Strikes does not depend on an unsuccessful motion because once a inotion is made, there is either an express finding or a transfer to adult court, either of which would lead to strike treatment. ${ }^{155}$ This reading of the statute elevates the discretion of the prosecutor over that of the judge and is thus consistent with the prosecutorial discretion underlying Three Strikes jurisprudence. ${ }^{156}$

This reading, rejected by the majority in Davis, rationally deals with the problem of offense heterogeneity. The severity and circumstances of the offenses varies greatly, both of those listed as serious or violent, and of those listed in section 707(b). The degree of reprehensible conduct constituting an assault or a residential-burglary adjudication can vary across a wide range. In most assault and residential burglary cases, especially those involving juveniles, who tend to succumb to peer pressure and to commit crimes in groups, ${ }^{157}$ the circumstances of the offense probably do not merit attaching lifelong criminal consequences. However, there may be circumstances that would support using these same offenses as triggers for sentence enhancements, including Three Strikes. ${ }^{158}$

151. See supra note 46 and accoinpanying text.

152. Cal. Welf. \& InST. Code $\$ 707$ (a) (Deering 1998).

153. See Cole, supra note 45 , at 346.

154. See CAL. Welf. \& INST. Code $\$ 602$ (Deering 1999).

155. Justice Kennard explained that whether a criminal act by a juvenile is a "strike" does not turn on whether the prosecution is successful in its attempt to have the minor tried as an adult; rather it turns on whether the prosecutor considers the crime so serious as to make the attenpt in the first place. People v. Davis, 938 P.2d 938, 948 (Cal. 1997) (Kennard, J., dissenting).

156. See supra notes $49-50$ and accompanying text.

157. See ZimRING, supra note 38, at 29-30, 78-80.

158. Justice Kennard recognized this problem of heterogeneity in his dissenting opinion: 
Rather than granting the judge primary discretion by drawing the line at the judge's fitness determination, the statute draws the line at cases where the prosecutor deemed the conduct severe enough to warrant the petition for transfer. Thus, an express finding-of-fitness requirement would provide a screening device that overcomes the problem of offense heterogeneity. In placing the screen at the petition-for-transfer stage, the statute favors the discretion of the prosecutor over that of the judge. ${ }^{159}$

Further, "even a severe limitation" on the set of juvenile adjudications that constitute strikes "may not be out of place"160 because the scope of possible strikes for juvenile adjudications is broader than the scope of possible strikes for adult convictions. ${ }^{161}$ Some of the offenses listed in Welfare and Institutions Code section 707(b) are not included in the list of serious or violent offenses that may count as strikes if they result from a criminal conviction. ${ }^{162}$ Thus, those offenses could count as strikes when a juvenile commits them, but the same offenses are not potential strikes when an adult commits them. ${ }^{163}$

\section{c. The Court's Interpretation is in Derogation of the Juvenile Court}

The express finding-of-fitness requirement would provide an independent screen based on the severity of the offense that would hinge the eligibility of a prior juvenile adjudication on the determination by the prosecutor in the juvenile court at the time of the offense. ${ }^{164}$ It would isolate those cases where there is a clear record that the prosecutor in the juvenile court considered the offense sufficiently serious or the offender particularly dangerous or unamenable to treatment so as to warrant a transfer to criminal court. The prosecutor for the current offense has the ability

Some 16-year-old delinquents are already dangerous, violent criminals. But there may be others whose acts reflect youthful immaturity rather than a commitment to crime. Perhaps it was a concern not to subject juvenile offenders in the latter category to the harsh penalties of the new Three Strikes law that led the Legislature ... to include within the class of "strikes" only those crimes that, in the prosecutor's view, were so serious as to require trying the minor as an adult.

Davis, 938 P.2d at 947 (Kennard, J., dissenting).

159. Justice Mosk adopted this view in his dissent, concluding that requiring an express finding was not inconsistent with the legislative intent to punish recidivists more harshly. Id. at 944 (Mosk, J., dissenting) (explaining that "we may deem it a kind of screening device, separating classes of juveniles-those as to whom a doubt about fitness had been raised (albeit subsequently resolved), and those as to whom such a doubt had not"').

160. Id.

161. Id. at $944-45$.

162. Compare Cal. Welf. \&. Inst. Code $\S 707$ (b) (Deering 1998), with Cal. Penal Code $\$ \S$ 667.5 and 1192.7 (Deering 1998). See also CaL. Penal Code $\$ 667$ (d)(1) (Deering 1998) (referencing $\S \S 667.5$ and 1192.7$)$.

163. See Cal. Penal, Code $\$ 667(d)(1)-(3)$ (Deering 1998).

164. See CAL. Welf. \& INST. CoDE $§ 707$ (a) (Deering 1998) (listing factors that the juvenile court is to consider in the fitness hearing as the degree of criminal sophistication, whether the minor can be rehabilitated, the minor's previous delinquent history, the success of previous attempts by the juvenile court to rehabilitate the minor, and the circumstances and gravity of the offense alleged). 
to make a charge or to disregard prior strikes based on his current view of the severity of the prior offense. After Romero, the Davis court should have recognized that this record could be helpful for a future judge deciding whether the inclusion of the juvenile adjudication as a strike was in the interests of justice.

The Davis court's interpretation completely removed the role of the juvenile court prosecutor as an independent screen for determining which adjudications would merit harsh consequences in the event of later adult convictions. Such an interpretation derogates the juvenile justice system's power by weakening the influence of the juvenile court prosecutor's judgment about the severity of juvenile crime on the uses of that crime as a later aggravation of punishment in the criminal justice system. The court should have considered the effect that this broad interpretation of Three Strikes would have on other juvenile justice and adult crimmal justice schemes. The court should also have made every effort to uphold the principles and procedures of the juvenile court in the absence of an express intent in Three Strikes to do otherwise. Thus, the court should have strictly interpreted Three Strikes to minimize the harm to the juvenile system.

\section{d. The Court Ignored Traditional Canons of Statutory Interpretation}

The Davis court ignored traditional canons of statutory interpretation in three different ways. First, the court completely ignored the plain meaning of the statute, which was not ambiguous and did not require an examination of legislative intent. ${ }^{165}$ Most naturally read, the statute requires an express finding of fitness. Instead, the court ignored traditional canons of statutory construction by trying to discern the legislative intent behind the provision even though there was no ambiguity to resolve. ${ }^{166}$ Second, the court adopted an interpretation that rendered an entire subdivision of the statute meaningless. ${ }^{167}$ Because the court concluded that the statute required only an implied finding of fitness, which it found implicit in every juvenile adjudication, section 667 (d)(3)(C) no longer serves any purpose. ${ }^{168}$ Third, the court failed to apply the rule of lenity, which requires a court interpreting an ambiguous statute to adopt the interpretation that provides less-harsh consequences for the defendant. Although there is no real

165. See Davis, 938 P.2d at 947 (Kennard, J., dissenting). ("[T] face of the language of section 667 , subdivision (d)(3)(C), which says nothing about 'implied' findings.").

166. See id. at 948 (Kennard, J., dissenting).

167. Justice Kennard stated that the majority completely disregarded a "cardinal rule of statutory construction, that courts should avoid a construction that makes some words surplusage," to the extent that they "construed an entire subdivision out of existence." Id. at 947 (Kennard, J., dissenting). Justice Mosk also criticized the majority because its interpretation left no function for paragraph (d)(3)(C). Id. at 944 (Mosk. J., dissentmg).

168. Id. 
ambiguity in section $667(\mathrm{~d})(3)(\mathrm{C})$, once the court concluded that the statute was ambiguous, it should have applied the rule of lenity.

In addition to the three violations of traditional canons of statutory construction, the court did not correctly apply the legislative intent. The court defended its decision using a generalized statement about the intent of Three Strikes to punish recidivists more harshly, ${ }^{169}$ but it failed to acknowledge the precise purpose of the statute-to "ensure greater punishments for those ... who have previously been convicted of serious and/or violent felonies." 170 This precise purpose refers only to felonies and not to juvenile adjudications. Moreover, it refers only to serious or violent felonies, and the scope of juvenile adjudications at the time of Davis was broader than this specified set of crimes. Neither the provision at issue nor the stated purpose of Three Strikes supports the result adopted by the court in Davis.

Practically, Davis's impact might be curtailed by Romero's holding that judges have the discretion to dismiss strikes. ${ }^{171}$ Thus, in cases in which a judge finds that counting juvenile adjudications as strikes would not be in the furtherance of justice, the judge could simply dismiss them. But relying on trial courts to dismiss strikes on a case-by-case basis shifts the pressure of public scrutiny to individual judges when the supreme court should have simply narrowed the scope of eligible juvenile adjudications. It also increases the potential for disparity of treatment from judge to judge. The ability of trial courts to limit the practical impact of Davis by applying Romero does not excuse the Davis court's poor judicial reasoning or its failure to follow any consistent line of reasoning or judicial method.

\section{B. People v. Garcia: Statutory Language Triumphs}

In 1999, the California Supreme Court revisited the juvenile adjudication provision and addressed the issue "left for another day" in Davis. Rather than let punitive intent trump all other principles, People $v$. Garcia $^{172}$ closely examined the statutory language and adopted an interpretation that narrowed the set of juvenile adjudications that constitute prior strikes. Garcia may be one of the court's most courageous Three Strikes decisions, but it hardly demonstrates candor in judicial method. The same seven supreme court justices interpreted another part of the very provision that had been at issue only two years earlier in Davis, but they applied reasoning and methods of statutory construction contradictory to those employed in Davis without acknowledging the inconsistency. Although the Davis court had managed to avoid confronting the seeming inconsistency between the two prongs of section $667(\mathrm{~d})(3)$ that outline

169. Id. at 940 .

170. Cal. Penal Code $\S 667$ (b) (Deering 1998).

171. See supra notes $98-03$ and accompanying text.

172. 980 P.2d 829 (Cal. 1999). 
between the two prongs of section 667(d)(3) that outline which statutory offenses can count as strikes, the court eventually had to face the issue. Despite the substantial overlap between the crimes listed in Welfare and Institutions Code section 707(b) and the crimes categorized as serious or violent in the Penal Code, there are some differences that create inconsistency. ${ }^{173}$ The seeming contradiction within section 667 (d)(3) had caused great confusion among courts, and the supreme court had to step in and clearly define the set of juvenile adjudications that could count as strikes. ${ }^{174}$

\section{The Garcia Decision}

In People v. Garcia ${ }^{175}$ the California Supreme Court resolved the conflict between paragraphs (B) and (D) of section 667(d)(3), holding that residential burglary juvenile adjudications could not count as strikes because they are not listed in Welfare and Institutions Code section 707(b) as required by paragraph (D). Garcia was charged with one count of residential burglary and one count of possession of burglar's tools. ${ }^{176}$ The trial court found four prior juvenile adjudications for residential burglary to be strikes even though residential burglary is not listed in Welfare and Institutions Code section 707(b). ${ }^{177}$ The prosecutor moved to have three of the prior adjudications dismissed, and the court granted the motion. The court sentenced Garcia under the second-strike provision to eight years in prison, doubling the four-year sentence it would otherwise have imposed for the burglary. ${ }^{178}$ The court of appeal affirmed, holding that the legislature's failure to include a reference to "serious and violent" offenses in paragraph (D) was a "drafting oversight" that required judicial correction. ${ }^{179}$

173. Some offenses listed in section 707 are not in the list of serious or violent crimes, such as discharging a weapon in an inhabited building, dissuading a witness or suborning perjury, manufacturing controlled substances, and escaping froin a juvenile hall. Soine serious or violent crimes are not included in section 707, including rape not by force, violence, or threat of serious bodily harm, voluntary manslaughter, kidnapping a child under age fourteen, a felony in which the child inflicts great bodily harm, and residential burglary. Compare CAL. WELF. \& INST. CODE $§ 707$ (b) (Deering I998), with CAL. Penal Code $\$ \$ 667.5$ and 1192.7 (Deering 1998).

174. In the same year as Davis, the Fifth District decided the issue the opposite way in People $v$. Griggs, 69 Cal. Rptr. 2d 174 (Cal. Ct. App. 1997). The court stated that the literal meaning of section 667(d)(3) was contrary to apparent legislative intent and, thus, should not prevail. The court concluded that a drafting oversight was the only rational explanation for the omission of serious or violent felonies from subsection (D) and held that serious or violent offenses not listed in section 707(b) do count as strikes. Id. at 176. The rest of the cases that addressed the issue have since been depublished. See People v. Lewis, 85 Cal. Rptr. 2d 454 (Cal. Ct. App. 1999); People v. Gentry, 72 Cal. Rptr. 2d 797 (Cal. Ct. App. 1998); People v. Diller, 85 Cal. Rptr. 2d 720 (Cal. Ct. App. 1997).

175. 980 P.2d 829 (Cal. 1999).

176. Id. at 830 .

177. Id.

178. Id.

179. Id. 
The California Supreme Court rejected the court of appeal's holding that the failure to reference "serious or violent" offenses in subdivision 667(d)(3)(D) was necessarily a "drafting oversight," and it reversed the appellate court's holding that residential-burglary adjudications could count as strikes. ${ }^{180}$ The supreme court reasoned that because the sets of offenses referenced in paragraphs (B) and (D) are not exactly parallel, there would be "an internal conflict if the lists in paragraphs (B) and (D) were both understood as deflning the set of juvenile offenses qualifying as strikes."181 The court rejected all of the parties' proposed interpretations of the provision because they shared "a critical disqualifying feature as interpretations of the Three Strikes law." Specifically, they required the court to redraft or disregard a portion of the statute. ${ }^{182}$ Instead, the court adopted an interpretation that left the statute intact and "harmonize[d] all parts ... without altering or adding language to any part or rendering any part superfluous or a nullity." 183

The court interpreted paragraph (B) as describing the list of juvenile adjudications that qualify as strikes. It read paragraph (D) as an additional requirement that "in the prior juvenile proceedmg giving rise to the qualifying juvenile adjudication the juvenile have been adjudged a ward of the court because of a Welfare and Institutions Code section 707(b) offense, whether or not that offense was the same as the offense currently alleged as a strike." 184 The court painstakingly distinguished between its interpretation and a less-careful reading:

Under our interpretation, only paragraph (B) limits the set of offenses that may qualify as strikes when the subject of a juvenile adjudication; consistent with the law's general purpose, all "serious" and "violent" offenses may so qualify. Paragraphs (A), (C), and (D), under our interpretation, do not restrict possible qualifying juvenile offenses to a set narrower than the set of serious or violent adult offenses that may qualify as strikes, but merely set forth additional conditions to the use of a qualifying offense as a strike. ${ }^{185}$

The court premised its interpretation on "a close reading of the statutory language exactly as written," 186 claiming that its reading was "consistent with the general purpose of the Three Strikes statute: "to ensure longer prison sentences and greater punishment for those who commit a felony and have been previously convicted of serious and/or

180. Id. at $837-38$.
181. Id. at 831 .
182. Id. at 834 .
183. Id. at 833 .
184. Id. at 832.
185. Id. at 833 .
186. Id. at 832.


violent felony offenses." 187 The court defended its strained reconciliation by arguing that "[s]ince the Legislature, the initiative drafters, and the voters have enacted a scheme that includes an explicit requirement, for juvenile adjudications, that the juvenile was ... adjudged a ward [of the court] because of a ... section 707(b) offense, we must presume [they] did not regard that circumstance as a "fortuity." 188 The court reasoned that the requirement in (D) "may be seen as serving the purpose of ensuring that the crimes adjudicated in the prior proceeding included at least one offense 'so serious as to raise a presumption of unfitness for treatment in the juvenile court system." 189 The court also cited the rule of lenity as "provid[ing] guidance when the language of a penal statute is susceptible of two or more interpretations."190

\section{Garcia 's Recognition of Distinctions for Juvenile Adjudications and Restoration of Traditional Principles of Statutory Construction}

Despite the Garcia court's candid recognition that the Three Strikes statute restricts its application in the juvenile context to a limited set of prior juvenile adjudications, the court did not acknowledge that its opmion was in direct conflict with its recent decision in Davis. Nevertheless, the Garcia court avoided two of the siguificant failures of the Davis court. First, Garcia explicitly acknowledged that Three Strikes's drafters may have intended to impose restrictions on prior juvenile adjudications that were not placed on adult criminal convictions. Second, Garcia was faithful to longstanding principles of statutory construction.

\section{a. The Court Recognized the Intent to Differentiate Juvenile Adjudications from Other Strikes}

Although the Garcia court explicitly recognized for the first time that the legislature intended to make qualifying juvenile offenses a special and distinct group for the purposes of Three Strikes, it did so reluctantly. The Garcia majority ${ }^{191}$ and Justice Baxter's concurrence ${ }^{192}$ indicated that they were accommodating the literal reading of the statute despite their belief that the drafters may have intended otherwise. Only Justice Brown, who had authored the majority opinion in Davis, recognized the severity of the consequences of expanding the scope of juvenile adjudications that can qualify as strikes and the drafters' possible intent to place limits on the use of juvenile adjudications. ${ }^{193}$ Justice Brown noted that Three Strikes's use of

187. Id. at $\$ 33$ (quoting CaL. Penal Code $\S 667(\mathrm{~b})$ ).

188. Id. at 836 .

189. Id. (quoting Justice Brown, id. at 844 (Brown, J., concurring in part and dissenting in part)).

190. Id. at 835 .

191. See id. at 833.

192. See id. at 841 (Baxter, J., concurring).

193. See id. at 844 (Brown, J., concurring in part and dissenting in part). 
juvenile adjudications was "a sharp break in [the] practice" of not counting juvenile adjudications as criminal convictions for any purpose, and that the legislature may have intended that their use "should be limited to those offenses that are both serious or violent and so serious as to raise the presumption of unfitness for treatment in the juvenile court system."194

Noting the presence of the three other requirements in section 667(d)(3), the court stated that it "was patently not the Legislature's intent" to include all prior adjudications for serious or violent felonies. ${ }^{195}$ Thus, Garcia recognized, in contrast to Davis, that it could not be assumed that the drafters intended Three Strikes to enhance sentences after juvenile adjudications in the same way as sentences following adult convictions. Offenders whose prior strikes include only juvenile adjudications are firsttime felons, so the standard for holding their prior adjudications against them could reasonably have been intended to differ from the standard for prior adult convictions.

Although it acknowledged some intent to differentiate juvenile adjudications, the Garcia court indicated that the structure of the juvenile adjudication provision of the statute may have been the result of a drafting oversight. ${ }^{196}$ As in Davis, the court failed to consider that the legislature may have had a perfectly rational reason for distinguishing between the requirements listed in (B) and those in (D). The result is that some offenses that would qualify as strikes if they led to an adult conviction do not qualify as strikes if they resulted in a juvenile adjudication. As argued by the defendant in Garcia, this result is not necessarily the product of an inadvertent drafting error:

Tempering the use of juvenile priors to exclude the least serious of the serious (such as residential burglary and unarmed robbery) demonstrates a legislative restraint which is quite rational. While those who ascribe to the Legislature an exclusively "get tough" intent may have difficulty accepting anything shy of a total scorched earth policy in the Three Strikes law, there is certainly nothing "bizarre" about a mildly tempered application of juvenile priors. ${ }^{197}$

Thus, the legislature may have intended precisely such a result, and the court should have fully acknowledged this intended restraint. Nevertheless, the court did not recognize subdivision (D) as a valid and reasonable restriction on the set of juvenile adjudications that could count as strikes. The court seemed convinced that $(\mathrm{B})$ could be the only provision that restricted the set of qualifying juvenile adjudications because it did not

194. Id.

195. Id. at 836 .

196. Id. at 837 .

197. Petitioner's Brief on the Merits at 12, People v. Garcia, 980 P.2d 829 (Cal. 1999) (No. S059302). 
completely abandon the notion that the restriction imposed by paragraph (D) was the result of a drafting oversight. ${ }^{198}$

\section{b. The Court Was Faithful to Traditional Canons of Statutory Interpretation}

Unlike the Davis court, the Garcia court embraced traditional canons of statutory construction in its interpretation of Three Strikes. For example, the court looked first to the plain meaning of the statutory language. In addition, the court ultimately adopted an interpretation that gave ineaning to every provision of the subsection. The court did not examine the legislative intent behind Three Strikes until after it had concluded that the plain language of the provision was ambiguous. ${ }^{199}$ When it applied the legislative intent, the court parsed the legislature's actual language rather than recognizing a broad intention to punish recidivists more harshly. The court also properly einployed the rule of lenity by interpreting an ambiguous criminal provision in favor of the defendant. ${ }^{200}$

Despite its definitive answer regarding the strike eligibility of section 707(b) offenses that are not serious or violent, the Garcia court did not completely resolve the problem surrounding the construction of the statute. After Garcia, it is clear that serious or violent offenses not listed in section 707(b) do not constitute strikes, but nonserious and nonviolent offenses that are listed in section 707(b) may still count as strikes. ${ }^{201}$ The result is that some offenses will count as strikes when committed by a juvenile adjudged a delinquent, but the very same offenses would not count as strikes if committed after the offender turns eighteen. A few appellate court opinions have held that, because there is no rational reason that the legislature would make the sphere of juvenile adjudications that can count as strikes

198. Garcia, 980 P.2d at 833,837 . Justice Baxter's concurrence, consistent with the majority in Davis, refused to recognize any intent to distinguish between the sphere of offenses that would constitute strikes if committed by a juvenile and the set of offenses that would constitute strikes if committed by an adult. Id. at 841 (Baxter, J., concurring)

Such a construction of paragraph (D) effectively eliminates a whole category of felonies referenced in paragraph (B) that were obviously intended to be mcluded as potentially qualifying Three Strikes prior juvenile adjudications, and in so doing contravenes the spirit, if not the letter, of the habitual offender enhancement provisions of the Three Strikes law. Id.

199. See, e.g., Wells v. Marina City Props., Inc., 632 P.2d 217, 221 (Cal. 1981) (statutes "should be construed so as to harmonize [their] various elements without doing violence to [their] language or spirit").

200. See Keeler v. Superior Court, 470 P.2d 617, 624 (Cal. 1970) (explaining that under the rule of lenity, courts generally "construe a penal statute as favorably to the defendant as its language and the circumstances of its application may reasonably permit ...").

201. The Fifth District Court of Appeal addressed this issue in People v. Leng, 83 Cal. Rptr. $2 d$ 433, 435 (Cal. Ct. App. 1999), holding that a juvenile adjudication listed in section 707(b), but nonetheless nonserious and nonviolent, does not qualify as a strike. The interpretation rested on both its conipliance with the right to equal protection of the laws under the Fourteenth Amendment, see id. at 439-40, and its consistency with the legislative intent of the statute. See id. at 441-42. 
broader than the sphere of adult convictions that count as strikes, ${ }^{202}$ only those offenses that are both serious or violent and listed in section 707(b) can count as strikes. ${ }^{203}$ The supreme court has not revisited the interpretation of this subsection since Garcia. Thus, this question has been left open, and the incompatible Davis and Garcia interpretations of section 667(d)(3) both ostensibly remain good law.

\section{Unresolved Tensions}

1. The Clash of PurposesBetween the Rehabilitative Emphasis of the Juvenile Justice System and the Punitive Intent of Three Strikes

Despite the supreme court's ruling in Garcia, the courts have not fully addressed the clash between the juvenile justice system and Three Strikes. Moreover, several appellate court opinions have upheld the constitutionality of using nonjury-trial juvenile adjudications as strikes, without really acknowledging the conflict between juvenile justice's premise of rehabilitation and the unforgiving permanent consequences of Three Strikes. ${ }^{204}$ The California Supreme Court has yet to address this issue. In Garcia, the supreme court discussed only the words of the statute, with no mention of constitutional concerns surrounding the use of juvenile adjudications as strikes. ${ }^{205}$ The Garcia court recognized an intended legislative distinction between juvenile adjudications and adult convictions that count as strikes, but it allowed the possibility that some qualifying juvenile adjudications would not count as strikes if committed by adults. This circumstance raises equal protection concerns on top of the existing due process concerns about using any juvenile adjudication as a strike because there is no right to a trial by jury in juvenile court.

\section{Irreconcilable Supreme Court Precedents: Garcia's Silent Overruling of Davis}

In the time between the Davis and Garcia decisions, the California Supreme Court completely changed its stance on the proper judicial method of statutory interpretation with respect to Three Strikes. Perhaps the justices believed that they should not agonize over every word of a poorly written statute imposed upon them by the democratic initiative process. ${ }^{206}$ Perhaps the court was attempting to demonstrate to the

202. See id. at 442 .

203. See id.

204. See supra note 140 and accompanying text. See also, e.g., In re Myresheia W., 72 Cal. Rptr. $2 \mathrm{~d}$ 65, 69 (Cal. Ct. App. 1998) ("The Three Strikes use of a juvenile adjudication in sentencing does not alter the treatment purpose of the previous juvenile adjudication.").

205. See Garcia, 980 P.2d at 844-45 (Brown, J., concurring in part and dissenting in part).

206. For a discussion of the complexity in initiative voting, see DuBoIs \& FEENEY, supra note 86, at 113-80. For an analysis of the California experience, see $i d$. at 22-26. 
legislature just how poorly the statute was written. ${ }^{207}$ The most likely explanation, however, seems to be that the court had simply gained confidence in this area by the time Garcia was decided. The supreme court had survived its Romero decision unscathed, and more time had passed since the passage of Three Strikes. Indeed, the Garcia decision sparked little reaction: as one observer noted " $[t]$ he latest ruling has barely caused a ripple in the legal community ... [b]ut while this ruling may have a minor impact on its own, what it does represent is the ongoing chiseling away of the three-strikes law ....".208

When the two decisions are juxtaposed, it is clear that the methods used in Garcia undermine any confidence that Davis is still good law. The Garcia court should have overruled Davis, but instead it almost failed to mention it. In summing up its vision of how Three Strikes should be interpreted, the Garcia court held:

It matters not whether the drafters, voters or legislators consciously considered all the effects and interrelationships of the provisions they wrote and enacted. We must take the language of section $[667(d)(3)]$ as it was passed into law, and must, if possible without doing violence to the language and the spirit of the law, interpret it so as to harmonize and give effect to all its provisions. ${ }^{209}$

Even this capsule summary of the court's methods makes clear that Davis cannot stand after Garcia. The Davis court did the opposite of what the Garcia instructions mandate. It conducted an inappropriate inquiry into legislative intent, failed to consider the language as it was passed, did violence to the language and the spirit of the law, and failed to harmonize all of the law's provisions.

If the specific rules of construction in Garcia had been applied in Davis, they would have yielded the opposite result. First, if "disregard[ing] ... some portion of the statute" is "a critical disqualifying feature" of a particular interpretation, then the finding-of-fitness requirement in section $667(d)(3)(C)$ would have to serve soine function. ${ }^{210} \mathrm{Sec}-$ ond, if the Davis court conducted "a close reading of the statutory language exactly as written,"211 it would have recognized that paragraph (C) tracks the language of the fitness hearing provisions in section 707(b) and concluded that an express finding was required. Third, the inclusion of the

207. In a recent case, Justice Werdegar expressed her frustration with the "ongoing series of recent challenges to portions of Three Strikes, whose drafting shortcomings have required this court to bridge the gap, fill in the blanks, resolve the conflicts, and fashion what in some cases is a regrettably complex scheme of criminal procedure." In re Cervera, I6 P.3d 176, I85 (Cal. 200I) (Werdegar, J., concurring).

208. Leslie Wolf Branscomb, S.D. Appeal Clarifies 3-Strikes Law on Juvenile Offenses, SAN Diego UnION-TRIB., July 3I, 1999, at A3; see also Harriet Chiang, Supreme Court Curbs "Three Strikes" Sentencing: Some Juvenile Cases Will Not Be Counted, S.F. Chron., July 30, I999, at AI9.

209. Garcia, 980 P.2d. at 837.

2I0. Id. at 834 .

2II. Id, at 832 . 
finding-of-fitness requirement should have forced the court to "presume that [the legislature] did not regard that circumstance as a fortuity."212 Finally, if the rule of lenity had been applied in Dovis, as it was in Garcia, ${ }^{213}$ the Davis court would have adopted a narrower reading of the paragraph requiring an express finding of fitness.

The principles of statutory construction in Garcia are sound and should be consistently applied in the interpretation of Three Strikes and other criminal statutes. Although the court took a courageous step in Garcia by restricting the scope of juvenile adjudications, it should have exercised candor. Instead of pretending that Davis merely left open the question decided in Garcia, the court should have confronted the contradictions in the cases head-on. At least one appellate court has applied the principles of Garcia to recognize that the juvenile adjudication provision in Three Strikes should be interpreted "narrowly according to its terms."214 Davis indicates precisely the opposite, and its overruling would be a doctrinal improvement in California law, both in general and in the realm of juvenile crime under Three Strikes. Until the court overrules Davis, however, there are other ways that trial and appellate courts, juvenile courts, and the legislature can mitigate the conflict between the two cases, a confiict which undoubtedly resulted from the tension between the punitive intent of Three Strikes and the rehabilitative spirit of juvenile justice.

\section{IV}

\section{Resolving THE CONFLICT}

Garcia destroyed the entire framework of Davis. Most significantly, the Garcia court explicitly recognized as false the Davis court's presumption that the legislature could not possibly have intended to distingnish between juvenile adjudications and adult convictions. In the wake of Garcia and Davis, the criminal courts, the legislature, and the juvenile courts can all take steps to recognize this intentional distinction and mitigate the conflict between the harsh permanent consequences of Three Strikes and the rehabilitative premise of the juvenile courts. First, the California Supreme Court should explicitly overrule Davis, using the statutory interpretation primciples of Garcia to promote the narrow construction of the provision governing the use of juvenile adjudications as strikes. If juvenile adjudications remain potential strikes, trial courts, juvenile courts, and appellate courts should all take steps to prevent the attachment of the Three Strikes law's harsh mandatory punitive consequences to juvenile adjudications, either across-the-board or in appropriate classes of cases.

212. Id. at 836 .

213. See id. at 835 .

214. In re Jensen, 111 Cal. Rptr. 2d 751, 754 (Cal. Ct. App. 2001). 
Regardless of what the courts do, the legislature should amend Three Strikes to preclude the use of prior juvenile adjudications as strikes.

\section{A. The California Supreme Court Should Expressly Overrule Davis}

The Davis and Garcia decisions are representative of the California Supreme Court's Three Strikes jurisprudence. The court's two inconsistent arsenals of statutory construction principles result in diametrically opposed results. When the court decides that get-tough intent should prevail, it finds precedent for that approach in Davis. When the court decides that the traditional canons of statutory construction should trump the overarching notion of get-tough intent, it can use Garcia to reeoncile its decision with the legislative intent behind Three Strikes. The supreme court should take a step toward rectifying this contradicting jurisprudence by explicitly overrulimg Davis.

The incompatibility of the California Supreme Court's methods suggests that something other than traditional canons of statutory construction has been driving the court's decisions. As Justice Kennard implored the court, "[f]or the sake of the predictability and stability of the law, our guidepost in interpreting Three Strikes must be the usual principles of statutory construction that apply in every case, not our projections of the hopes and fears that led to the statute's enactment."215 The justices should be collectively candid about Three Strikes jurisprudence in general and juvenile adjudications im particular. "As daunting as the task might be, a coherent theory of what the statute is attempting to achieve would seem to be an important aspect of resolving disputes about the meaning and scope of the statutory language."216 The methods and rules used by the court have a siguificant impact on all state decisions. Bringing the court's Three Strikes jurisprudence back into the main traditions of its work will enhance the court's stature and the law's predictability.

Trial judges' discretion to dismiss strikes in the wake of Romero may make it less likely that the California Supreme Court will revisit the issue and expressly overrule Davis. However, the potential for Romero to undo the practical impact of Davis is not a valid reason for leaving Davis intact. To some extent, Romero turns the criminal court judge imto the referee that decides which juvenile adjudications will count as strikes. Relying on Romero instead of overturning Davis undermines the authority of the juvenile courts. ${ }^{217}$ Although Romero allows the criminal court judge to dismiss juvenile adjudications, the judgment as to whether a juvenile adjudication warrants strike treatment should be made in the juvenile court at the time of the original offense. Juvenile court prosecutors and judges have far more

215. People v. Davis, 938 P.2d 938, 949 (Cal. 1997) (Kennard, J., dissenting).

216. ZimRing ET AL., PUnishment ANd Democracy, supra note 4, at 132.

217. See supra Part III.A.2.c. 
information about the offense and the offender, and this special expertise should be given great weight in determining whether that offense warranted permanent punitive consequences. The plain language of Three Strikes allows the use of juvenile adjudications where there has been a finding of fitness. ${ }^{218}$ This language was adopted from the code governing juvenile court procedures, and it indicates an intent to respect those procedures. In the absence of express intent to alter the juvenile court law, the court should adopt a construction of Three Strikcs that recognizes a real finding of fitness requirement and therefore does minimum harm to the juvenile court system.

\section{B. Trial Courts Should Recognize that Garcia Has Undermined Davis}

Although the Garcia court was unwilling to overrule Davis, the Garcia opinion nevertheless provides a basis for other courts to overcome the result in Davis. If the supreme court does not explicitly overrule Davis, trial and appellate courts should acknowledge that the supreme court's opinion in Garcia stripped away all of the rationale for Davis, and they should refuse to invoke the statutory construction principles employed in Davis. Even if trial judges do not want to take a visible stand against the Davis result, they can use the discretion made available by Romero to dismiss every prior strike that resulted from a juvenile adjudication lacking an express finding of fitness. ${ }^{219}$ If the prosecutor at the time felt that the offense was not of such a serious nature that it should be transferred to criminal court, the judge could easily argue that counting such adjudication as a strike would not be "in furtherance of justice."

\section{Appellate Courts Should Formulate Romero Guidelines that Encourage Striking Certain Juvenile Adjudications}

Defendants may not have to rely exclusively on trial judges to grant their motions to dismiss prior strikes. To establish consistency among trial courts, appellate courts can establish broadly applicable standards under Romero governing the dismissal of juvenile adjudications as strikes. A trial court's refusal to dismiss juvenile adjudications, either across the board or in certain prescribed circumstances, could be deemed an abuse of discretion by appellate courts. If juvenile adjudications remain potential strikes, ideally appellate courts or the supreme court would formulate standards preventing the use of any juvenile adjudication as a strike. Alternatively, courts should find that it is always in the furtherance of justice to strike

218. Cal. Penal Code $\S 667(d)(3)(c)$.

219. Trial courts can selectively strike certain juvenile adjudications and leave the defendant's other strikes intact. People v. Garcia, 976 P.2d 831, 839 (Cal. 1999) (affirming dismissal of one of prior strikes because criminal history was not violent and prior offenses were committed during a "single period of aberrant behavior"). 
juvenile adjudications not tried in front of a jury, which would eliminate due process concerns. Courts should also formulate guidelines encouraging the dismissal of all adjudications that resulted in probation, because the juvenile court's selection of such a disposition may indicate that the juvenile court adjudged the minor a ward of the court so that it could treat the child rather than punish him. ${ }^{220}$ Lastly, if the supreme court does not explicitly overrule Davis, courts should require dismissal of all adjudications in which the prosecutor failed to move for transfer, ${ }^{221}$ which would effectively undo Davis. Although a decision seemingly motivated by nothing more than antipathy toward the Three Strikes scheme will unlikely withstand appellate scrutiny, a decision that clearly articulates why it fits within the standards set forth by the supreme court should withstand scrutiny. ${ }^{222}$ Garcia gives appellate courts precedent that can be used to justify judicially-crafted restrictions on juvenile adjudications.

The opportunities for appellate courts to formulate such Romero guidelines may be limited. For example, at least one court has held that there is only limited review available to a defendant whose motions for dismissal of prior convictions are denied. In People $v$. Benevides, the court of appeals concluded that because a defendant has no right to make a Romero motion, the trial court has no obligation to rule on the issue, and thus "there is no review available to defendant on appeal."223 However, the court did concede that the defendant has a right to appellate review "when a trial court's refusal or failure to exercise its section 1385 discretion to dismiss or strike was based on a mistaken belief regarding its authority to do so."224 Because the trial court had recognized its discretion to strike prior convictions, however, the court of appeals summarily rejected the defendant's claim that the trial court had abused its discretion. ${ }^{225}$

Other courts have allowed the denial of dismissal of strikes to be reviewed under an abuse-of-discretion standard, but most courts have concluded that the denial was a proper exercise of the trial court's discretion. ${ }^{226}$ As one court found, " $t]$ he overwhelming inajority of California appellate courts have reversed the dismissal of, or affirmed the refusal to dismiss, a

\footnotetext{
220. See supra notes 29-31 and accompanying text.

221. See supra Part III.A.2.b.

222. See supra notes $99-03$ and accompanying text.

223. People v. Benevides, 75 Cal. Rptr. 2d 388, 392 (Cal. Ct. App. 1998).

224. Id.

225. Id. at 393.
}

226. See, e.g., People v. Stone, 89 Cal. Rptr. 2d 401, 407 (Cal. Ct. App. 1999) (concluding that defendant could not be deemed outside the spirit of Three Strikes and thus the trial court did not abuse its discretion in failing to dismiss a strike); People v. Barrera, 82 Cal. Rptr. 2d 755 (Cal. Ct. App. 1999) (finding that trial court's refusal to dismiss was justified based on a criminal history with eleven misdemeanors, three felonies, and numerous parole violations); People v. Myers, 81 Cal. Rptr. 2d 564, 565 (Cal. Ct. App. 1999) (affirming trial court's denial of dismissal of strikes, even though the court explained its decision only in terms of the violence of defendant's crimes, because the court is presumed to have considered all relevant factors whether or not it explains them all). 
strike of those defendants with a long and continuous criminal career."227 Several cases have found abuse of trial court discretion in striking prior convictions for Three Strikes purposes. ${ }^{228}$ Nevertheless, there have been a few cases in which appellate court affirmed the dismissal of a strike by a trial court. ${ }^{229}$

Although most appellate courts have not been very aggressive in reviewing trial court denials of motions to dismiss strikes, a few have reversed and remanded for reconsideration. ${ }^{230}$ An appellate court in People $v$. Cluff" concluded that "the trial court abused its discretion when it denied [defendant's] motion to strike one or more of his priors."232 The court vacated the twenty-five-years-to-life sentence and remanded the case,

227. People v. Strong, 104 Cal. Rptr. 2d 490, 497 (Cal. Ct. App. 2001).

228. E.g., People v. Strong, 104 Cal. Rptr. 2d 490, 492 (Cal. Ct. App. 2001) (ordering that on remand the trial court reinstate a strike that it had dismissed because it was an abuse of discretion to deem a career criminal to be outside the spirit of Three Strikes and rely on the fact that the defendant had reached an advanced age and represented a reduced risk to society); People v. Gaston, $87 \mathrm{Cal}$. Rptr. $2 \mathrm{~d} 829$ (Cal. Ct. App. 1999) (reversing a trial court dismissal of a seventeen-year-old strike because the defendant was the kind of criminal for whom Three Strikes was designed); People v. Thornton, $86 \mathrm{Cal}$. Rptr. 2d 84, 89 (Cal. Ct. App. 1999) (reversing a trial court order dismissing two of three prior strikes because it did not properly take account of defendant's "dismal" background, character, and prospects, and long criminal career); People v. McGlothin, 79 Cal. Rptr. 2d 83, 87 (Cal. Ct. App. 1998) (stating that a decision to strike was improperly based on antipathy to Three Strikes because neither present crimes nor prior strikes supported decision); People v. Humphrey, 68 Cal. Rptr. 2d 269 (Cal. Ct. App. 1997) (reversing a trial court order dismissing prior conviction because defendant has led a continuous life of crime since the prior conviction); People v. Smith, 58 Cal. Rptr. 2d 9, 15 (Cal. Ct. App. 1996) (concluding that decision to strike was based on antipathy to Three Strikes and noting that trial court failed to provide reasons for striking prior convictions); People v. Carter, 56 Cal. Rptr. 2d 689, 695 (Cal. Ct. App. 1996) (finding that failure to explain reasons for dismissal and the fact that dismissal was granted to facilitate a plea necessitated remand); People v. Ramos, 55 Cal. Rptr. 2d 1, 4 (Cal. Ct. App. 1996) (concluding that it was improper for trial court to strike prior conviction simply because defendant pleaded guilty).

229. See, e.g., In re Saldana, 67 Cal. Rptr. 2d 183 (Cal. Ct. App. 1997) (affirming trial court's exercise of discretion to strike a strike where the current offense was relatively minor and the strike was sixteen years old); People v. Bishop, 66 Cal. Rptr. 2d 347 (Cal. Ct. App. 1997) (upholding trial court's exercise of discretion to dismiss two of defendant's three strikes where all three strikes were close to twenty years before the current offense of petty theft). Both Saldana and Bishop predated the California Supreme Court's decision in People v. Williams, 948 P.2d 429 (Cal. 1998), which sets forth the curtent standard, so they may not be as relevant today.

230. In People v. Taylor, 95 Cal. Rptr. 2d 357, 365-67 (Cal. Ct. App. 2000), rev. granted, 99 Cal. Rptr. 2d 744 (Cal. Aug. 23, 2000) (No. S088909) the court of appeals found prejudicial error and remanded the case because the trial court had considered inappropriate factors in its refusal to dismiss the defendant's prior strikes. The court of appeals indicated factors pointing in both directions, but it concluded that the trial court's refusal was influenced by the defendant's behavior in court in the course of representing himself and by the fact that the court considered the defendant a public nuisance. Thus, the sentence was vacated and remanded for resentencing without consideration of the two improper factors. Id.

231. 105 Cal. Rptr. 2d 80, 81 (Cal. Ct. App. 2001).

232. Id. 
emphasizing to the trial court that "there are strong arguments that Cluff should be treated as though he fell outside the Three Strikes scheme."233

The Cluff court listed several factors that weigh in favor of dismissing a strike, and instructed the trial court to "consider all of these factors $\mathrm{m}$ exercising its discretion to strike one or more of the prior convictions." 234 In Cluff, the current offense was "the most technical violation" of a sexual offender registration law. ${ }^{235}$ The failure to comply with the registration requirement was the defendant's only offense since his arrest in 1984 and release from prison in 1990. The court of appeal found it relevant that the defendant was regularly employed, that there was no evidence that he had reoffended, and that the record strongly suggested that the defendant had committed only a "technical" violation of the registration requirement without any intent to deceive or evade authorities. ${ }^{236}$ The Cluff court concluded that "the trial court's analysis became disconnected from the evidence and entered the realm of imagination, speculation, supposition, and guesswork."237

The Cluff court also ruled that it was an abuse of discretion to conclude that no strikes should be dismissed. ${ }^{238}$ Cluff may be a powerful tool for developing substantive Romero guidelines because the court disagreed with the trial court's conclusion, not its process. Using Cluff as a starting point, appellate courts should begin to reverse trial court refusals to dismiss juvenile adjudications as strikes. If appellate courts begin to overturn trial court decisions that refuse to strike juvenile adjudications so as to formulate clear guidelines under Romero, then Davis could effectively be undone on an institutional, not just an individualized, scale.

Unfortunately, many appellate courts may be unwilling to formulate such guidelmes because they want to avoid a course of action that might undermine Three Strikes. Also, both commentators and courts have noted that once a juvenile reoffends as an adult, his juvenile record really becomes part of his crimimal history, and it should be applied accordingly to enhance his sentence. ${ }^{239}$ If the crimes that trigger Three Strikes had to be

233. Id. at 88. The court noted that "the severe penalty imposed... appears disproportionate by any measure." $I d$. at 87 .

234. Id. (stating that the nature of defendant's current offense did not indicate recidivist tendencies, none of the aggravating circuinstances seemed to apply, and some mitigating circumstances may apply).

235. Id. at 81. The defendant had prior strikes consisting of child molestation offenses for which defendant was sentenced to nine years in prison. The defendant had complied with registration requirements from 1990, when he was released from prison, until 1995, when the police called and informed him that he had failed to annually renew his registration. The defendant had registered at his current address, but the annual renewal requirement had been added after he initially registered. Id.

236. Id. at 86 .

237. Id.

238. Id.

239. See Sanborn, supra note 46, at 208-09 (noting that proponents of using juvenile adjudications as enhancements see no reason to forgive the juvenile once they reoffend); Deborah L. Mills, United 
serious or violent, this theory might provide powerful support for the use of prior juvenile adjudications as strikes. Because any felony can be the triggering offense, however, Three Strikes in California is driven much more by the prior conduct than by the current offense. ${ }^{240}$ As long as juvenile adjudications remain potential strikes, appellate courts should at least be willing to structure guidelines requiring the dismissal of prior juvenile adjudications as strikes when the triggering offense is a relatively minor one, such as petty theft or possession of a small amount of drugs.

\section{Legislative Reform of Three Strikes or the Juvenile Courts}

Thus far, all of the steps to clarify, modify, or mitigate the impact of Three Strikes have been taken by the courts. Its record on Three Strikes, though, has left just as much confusion as that created by the original wording of the statute. The supreme court is not entirely to blame for the jurisprudence surrounding Three Strikes; the drafters of the statute provided the courts with a poorly drafted law unaccompanied by any meaningful legislative history. The court has indicated that the legislature ought to clarify the wording of the statute. ${ }^{241}$ The legislature should accept the court's invitation to clarify Three Strikes. In no area is such clarification more necessary, or less likely to be controversial, than in the area of juvenile adjudications used as strikes.

The legislature should completely defuse the tension between the punitive intent of Three Strikes and the rehabilitative aspect of juvenile justice by reforming Three Strikes to eliminate juvenile adjudications as prior strikes, so that only those young offenders transferred to criminal court would acquire strikes. As an alternative, if the legislature is unwilling to prevent the use of juvenile adjudications as strikes, it could leave Three

States v. Johnson: Acknowledging the Shift in the Juvenile Court System from Rehabilitation to Punishment, 45 DePaul L. Rev. 903, 940 (1996) (stating that if juveniles who grow up to be adult criminals are forgiven their juvenile offenses, it may appear that they are receiving a "double benefit from the system"- the benefit of juvcnile court over criminal court and the benefit of having their records expunged); People v. Fowler, 84 Cal. Rptr. 2d 874, 876 (Cal. Ct. App. 1999) (reasoning that "[b]y reoffcnding, a defendant shows he has failed to draw the proper lesson from the previous judicial determination that he violated the law" and that " $[\mathrm{t}] \mathrm{his}$ failure warrants harsher punishment in the adult proceeding").

240. Two recent Ninth Circuit decisions, addressing indeterminate life sentences under Three Strikes for petty theft with a prior, demonstrate the extent to which Three Strikes is driven by the prior offenses rather than the current conduct. See Brown v. Mayle, 283 F.3d 1019 ( $9^{\text {th }}$ Cir. 2002) (holding that a twenty-five-year-to-life sentence for a petty theft offender with two prior violent strikes was cruel and unusual punishment); Andrade v. Att'y Gen. of Cal., 270 F.3d 743 ( $9^{\text {th }}$ Cir. 2001), cert. granted, 70 U.S.L.W. 3497 (U.S. Apr. 1, 2002) (No. 01-1127) (holding that a fifty-year-to-life sentence for two petty theft convictions was cruel and unusual punishment, even considering criminal history including two prior strikes for residential burglary).

241. See People v. Garcia, 980 P.2d 829, 837-38 (Cal. 1999) (noting that the lack of parallelism in the juvenile adjudication provision "may well be the result of an oversight by the drafters" but that the task of revising it rests with the legislature); People v. Davis, 938 P.2d 938, 941 (Cal. 1997) (noting that the juvenile adjudication provision "is arguably superfluous in part no mattcr how we interpret it"). 
Strikes intact and amend juvenile court procedures to conform with the more formal protections guaranteed in crimmal courts. The use of juvenile adjudications as strikes is not consistent with the premise of diversion rehabilitation that justifies the lack of protections for defendants in the juvenile justice system in California. However, importing the formal procedures of criminal trials into juvenile courts could undermine the flexible, rehabilitative function of the juvenile justice system. ${ }^{242}$ Because of the distinctive characteristics and presumptions underlying the juvenile justice system, if juvenile offenses are counted as strikes the better solution would be to allow use of only those juvenile offenses that are transferred to adult court.

lronically, the passage of Proposition $21^{243}$ obviates the need to import the procedural protections of the criminal court into the juvenile justice system for the sake of alleviating due process concerns raised by attaching permanent punitive consequences to juvenile transgressions. The prosecutor can now ensure that many offenses count as strikes by filing charges directly in adult court. Proposition 21's easing of standards for transfer makes a legislative compromise restricting Three Strikes's application to juvenile offenses resulting in adult criminal convictions much more feasible in 2002 than it would have been under the restrictive waiver standards in existence when Three Strikes was passed in 1994. The prosecutor may now automatically file criminal charges in adult court for any juvenile sixteen years of age or older who commits an offense listed im Welfare and Institutions Code section 707(b). ${ }^{244}$ Thus, a prosecutor can ensure that any offender who meets only these two provisions of Penal Code section $667(d)(3)$ will receive a strike if they are convicted of the offense, because they can take the offender straight to adult court without a fitness determination from a juvenile court judge. There is no longer any need to allow juvenile adjudications to count as strikes.

If strikes include only those juvenile offenses tried in criminal court, then juvenile court prosecutors seeking Three Strikes consequences would have an incentive to flle charges in a forum that provides the procedural protections that should accompany a proceeding that could automatically enhance a subsequent criminal sentence. Under the current system, prosecutors may not feel much need to transfer juveniles to criminal court

242. See McKeiver v. Pennsylvania, 403 U.S. 528, 540 (1971) (plurality) (noting that the right to trial by jury is the due process right "which would most likely be disruptive of the unique nature of the juvenile process" and "would probably require substantial alteration of the traditional practices"); In re Myresheia W., 72 Cal. Rptr. 2d 65, 68 (Cal. Ct. App. 1998) (stating that juvenile proceedings "are intended to secure for the minor such care and guidance as will best serve the interests of the ininor); see also id. (describing special duties of juvenile judges and the requirement that juvenile court personnel take a different view of their role than their counterparts in the criminal courts).

243. See supra notes 32-36 and accompanying text.

244. CAL. Welf. \& INST. CODE $§ 707$ (d) (Deering 1998). 
because of the punitive consequences that Three Strikes assigns to juvenile offenses. In fact, because juveniles may actually be given lighter sentences in criminal court than in juvenile court, ${ }^{245}$ prosecutors may want to keep the juveniles in the nonjury juvenile court system. If juvenile offenses eligible for Three Strikes were limited to those tried in criminal court, then the state would be upholding its duty to protect the constitutional rights of those exposed to criminal punishment. Alternatively, the use of juvenile adjudications to enhance adult sentences could be limited to those juveniles who were afforded the same constitutional protections as criminal defendants similarly situated..$^{246}$

\section{E. Juvenile Court Judges Should Use Their Discretion to Prevent Later Applications of Three Strikes in Appropriate Cases}

The legislature is likely to continue its hands-off Three Strikes policy, especially considering the difficulty of achieving the supermajority necessary to amend the law, ${ }^{247}$ and the supreme court may continue to force trial court judges to use Romero to avoid any injustice created by its opinions. Thus, juvenile court judges may be a last resort; they can act within their discretion to prevent an application of Three Strikes to a later conviction in cases where they do not believe it is appropriate to attach permanent consequences to the adjudication. Juvenile court judges should be very mindful of the Three Strikes consequences of their rulings. Under the original premise of the juvenile court, the crucial inquiry was whether the child was in need of the rehabilitative services of juvenile court. But once that premise shifts and the consequences of a juvenile adjudication could lead to the doubling of a later criminal conviction or a mandatory twentyfive-years-to-life sentence, judges must be cautious in adjudicating delinquents. A judge who declares a juvenile a ward of the court for the purpose of placing the juvenile on probation in an attempt to rehabilitate him could generate perverse consequences. ${ }^{248}$

Juvenile court judges can use their discretion to lessen a charge to one not listed in California Welfare and Institutions Code section 707(b) in order to take it outside of the sphere of juvenile adjudications that count as strikes. Judges can lessen the charge without necessarily changing the

245. See Cathi J. Hunt, Note, Juvenile Sentencing: Effects of Recent Punitive Sentencing Legislation on Juvenile Offenders and a Proposal for Sentencing in the Juvenile Court, 19 B.C. THIRD WORLD L.J. 621, 657-58 (1999) (citing studies and arguing that transfer to criminal court may not be achieving its goal of harsher penalties because criminal court judges who have limited exposure to young offenders may be swayed by the youth's age and immaturity and thus impose a lenient sentence). See also Zierdt, supra note 39, at 413 (citing studies concluding that juveniles are more likely to be convicted of the same or similar crime in juvenile courts and that juveniles receive lighter sentences for property offenses in criminal court as compared to juvenile court).

246. Dormont, supra note 140, at 1771.

247. See Cal. Penal Code $§ 667(\mathrm{~h})$ (Deering 1998).

248. See supra note 29 and accompanying text. 
disposition because they have wide discretion in prescribing appropriate treatment. ${ }^{249}$ So, without any current cost, juvenile court judges can prevent permanent punitive consequences from attaching to juvenile indiscretions. As long as Davis's holding that every juvenile adjudication entails an implied finding of fitness stands, the juvenile court prosecutor's assessment of whether the offense or the offender was appropriate for transfer to adult criminal court need not be revisited by the crimmal court judge in a Three Strikes case. If a juvenile court judge does not consider the offense or the offender to be deserving of the harsh mandatory consequences of Three Strikes upon a later conviction, he or she should protect the juvenile by lessening the charge. However, given the changes in Proposition 21 which allow prosecutors unilaterally to sidestep the juvenile court system, the opportunity for juvenile court judges to play a role in influencing the ultimate consequences of offenses committed as a juvenile is likely to diminish.

\section{CONCLUSION}

The inclusion of juvenile adjudications as prior strikes under Three Strikes set up an inevitable clash between the remaining rehabilitative purposes of the juvenile justice system and the unrelenting punitive intent that motivated Three Strikes. Although juvenile adjudications were included as potential strikes, the provision governing their use specified four criteria that must be met before adjudications could be treated like adult felony convictions. Nevertheless, the California Supreine Court has been reluctant to recognize the legislature's clear intent to treat juvenile adjudications differently than other prior offenses.

The California Supreme Court, faced with a poorly written statute, has dealt with its ambiguities in a way that has further confused the rules and obfuscated the rationales. The court has ignored traditional canons of statutory construction and unjustifiably expanded the number of juvenile adjudications that count as strikes. In Garcia, when the court finally recognized a distinction for the use of juvenile adjudications as strikes, it did so reluctantly and without acknowledging that it was in effect overruling Davis.

Courts should resolve the tension created by Three Strikes's application to juvenile adjudications and exacerbated by the Davis and Garcia opinions. The suprene court should expressly overrule Davis, including its methods of statutory interpretation and its broadening of the scope of juvenile adjudications that qualify as prior strikes. In the meantime, trial and appellate courts should effectively reverse the Davis decision by using their discretion to dismiss juvenile adjudications that did not follow froin an express finding of fitness. Courts should also consider disinissing all juvenile adjudications, or at least those not tried in front of a jury. Appellate courts

249. GARDNER, supra note 18, at 305. See also supra notes 29-31 and accompanying text. 
should formulate guidelines for Romero hearings that encourage certain juvenile adjudications to be stricken in the interests of justice.

Although the legislature has yet to take any action to mitigate or clarify Three Strikes, it still has an opportunity to act. If legislators are looking for an area in which to test Three Strikes's aura of political invincibility, they should consider Three Strikes's application to prior juvenile adjudications. They have watched the court survive its teinpering of the mandatory impact of Three Strikes. And there is probably no area of Three Strikes where a weakening of the impact would be less controversial than in juvenile justice.

Lastly, if the incomprehensible Three Strikes jurisprudence on the use of juvenile adjudications remains intact, as seems most likely, juvenile court judges should use their discretion to circumvent the permanent consequences that Three Strikes attaches to juvenile adjudications, perhaps by diverting the juvenile to a lcsser conviction.

In the context of the clash between the rehabilitative aspect of juvenile justice and the punitive intent of Three Strikes, the inconsistency of the Davis and Garcia decisions may be understandable. But other institutions should seize their opportunities to undo the Davis decision and discourage or restrict the use of juvenile adjudications as strikes. The best resolution of the tension between Three Strikes and the juvenile justice system would be a legislative amendment or an initiative eliminating or restricting the use of juvenile adjudications as strikes. If neither the supreme court nor the legislature acts to resolve the conflict, juvenile court judges should use their discretion to lessen charges for offenses that do not seem worthy of Three Strikes's harsh punitive consequences, trial court judges should use their discretion to dismiss prior juvenile adjudications as strikes, and appellate courts should formulate guidelines suggesting that certain juvenile adjudications should be dismissed as strikes. 